\title{
Sosyal Medya Güncel Tartışmalar: Sosyal Medyanın Kontrolü \& Sosyal Medya Hizmet ve Gizlilik Sözleşmeleri \& Yerli ve Milli Sosyal Medya
}

Current Discussions on Social Media: Control of Social Media \& Service and Privacy Agreements for Social Media \& Domestic and National Social Media

Taylan GÜLASLAN

Dr., Serbest Araştırmacı, taylangulaslan@gmail.com https://orcid.org/0000-0002-5866-0808
Makale Başvuru Tarihi: 07.03.2021

Makale Kabul Tarihi: 11.04.2021

Makale Türü: Araştırma Makalesi

\section{ÖZET}

\section{Anahtar}

Kelimeler:

Sosyal Medyanin

Kontrolü,

Hizmet ve Gizlilik Sözleşmeleri,

Sosyal Medya

Yasaları.

Çevrimiçi Nefret

Söylemi,

Siber Zorbalık,

Keywords:

Control of Social Media,

Service and Privacy Agreements,

Social Media Laws,

Online Hate Speech,

Cyberbullying,
Dünya nüfusunun yarısından fazlası aktif sosyal medya kullanicısıdır. Bu mecrada farkl gerekçelerle vakit geçiren insanlar, sosyal medya şirketlerine önemli kişisel veriler sağlamakta ve adeta bu șirketlerin bir çalışanı haline dönüşmektedirler. Sosyal medya kullanımındaki artışla doğru orantılı olarak, bu mecrada siber zorbalık, nefret söylemi gibi yasa dışı içeriklerin sayısında da artış yaşanması, ülkeleri sosyal medyayı kontrol etmede ve güvenli siber ortamı tesis etmede yasal düzenlemeler yapmak zorunda bırakmıstır. Sosyal medya şirketleri de, ülkeler tarafindan yapılan düzenlemelere uygun olarak kendi hizmet ve gizlilik sözleşmelerini düzenli aralıklarla güncellemektedir. Çalışmamızda öncelikle seçilen ülke ve örgütlerin sosyal medya yasal düzenlemeleri ve çalışmaları incelenmiş, sosyal medya platformlarına ait hizmet ve gizlilik sözleşmeleri gözden geçirilmiş ve müteakiben yerli ve milli sosyal medya konusu tartışılmıştır. Bu bağlamda; özellikle ifade özgürlüğ̈̈nün ve demokrasinin merkezi kabul edilen ülkelerde bile sosyal medyayı kontrol altına almaya yönelik önemli yasal düzenlemelerin yapıldiğı görülmüştür. Yakın gelecekte sosyal medyanın kontrolüne dair düzenlemelerin uluslararası ortama doğru evrilebileceği sonucuna varılmıştır. Hizmet ve gizlilik sözleşmelerinin uzun metinlerden oluşması, okunsa dahi anlaşılmasının güç olması ve muğlâk ifadeler içermesi sebebiyle kullanıcılar aleyhine durumların ortaya çıma ihtimali yüksektir. Yerli ve milli sosyal medya çalışmaları kapsamında, Siber Vatan'ın güvenliğinin sağlanmasında tüm paydaşların sürece dâhil edildiği eylem planlarının hayata geçirilmesine ihtiyaç bulunmaktadır.

\section{ABSTRACT}

More than half of the world's population are active social media users. People who spend time in this channel for different reasons, provide important personal data to social media companies and become a employee of these companies. In line with the increase in the use of social media, the increase in the number of illegal content such as cyberbullying and hate speech in this domain has forced countries to make legal regulations in controlling social media and establishing a safer cyber environment. Social media companies also regularly update their service and privacy agreements accordingly the regulations made by the countries. In our study, social media legal regulations and studies of selected countries and organizations were examined, service and privacy agreements of social media platforms were reviewed, and then domestic and national social media issues were discussed. In this regard; it has been observed that important legal regulations have been made to control social media, even in the countries that are accepted as the center of freedom of expression and democracy. It has been concluded that in the near future, regulations regarding the control of social media may evolve into the international arena. Due to the fact that the service and privacy agreements consist of long texts, are difficult to understand even if they are read, and contain ambiguous expressions, the conditions against the users are likely to arise. Within the scope of domestic and national social media works, action plans in which all stakeholders are included in the process are needed to be implemented in ensuring the security of Cyber Homeland. 


\section{GİRiş}

İnsanların topluluk halinde yaşamaya başladığı andan itibaren yöntem ve şekilsel açıdan değişim gösterse de, bireylerin dış dünyası ile iletişim kurma / paylaşımda bulunma ve bir gruba ait olma arzu, istek ve ihtiyaçları geçerliliğini halen korumaktadır. Benzer ihtiyaçlar, günümüzün rekabetçi koşullarında herhangi bir ayırım yapmaksızın kamu ve özel sektörde kurumsal amacını gerçekleştirmek isteyen kurumlar, örgütler ve firmalar için de söz konusudur. Bilgi ve iletişim teknolojilerinde yaşanmakta olan baş döndürücü gelişmelere bağlı olarak, belirtilen ihtiyaçların karşılanma yöntemleri de kökten değişikliğe uğramış ve yeni uygulamaların ortaya çıkma süreci hızlanmıştır. Özellikle mobil cihazlar üzerinden internetin zaman ve mekândan bağımsız kullanımı, belirtilen sürecin adeta lokomotifi (driver) olmuştur. Kısaca ifade etmek gerekirse, internet, web ve mobil tabanlı teknolojilerdeki gelişimin merkezi haline gelmiş bu alan sosyal medyadan başkası değildir.

Kesin bir tanımı olmamakla birlikte, hakkında birçok tanımlama denemesinin yapıldığı (Kaplan ve Haenlein, 2010:61; Safko, 2021:4; Scott ve Jacka, 2013:5; Onat, 2010:105; Ertaş, 2015:19; Taşç1, 2010:73; Boyd, 2008:92) sosyal medyayı en basit şekilde, bireylerin ya da kurumların kendilerine fayda/kazanç sağlamak maksadıyla bağlantı, ilişki ve iletişim kurma, işbirliği geliştirme, etkileşim ve paylaşımda bulunma ile bir gruba/topluluğa katılma ihtiyaçlarının internet ve bilgi/iletişim teknolojileri temelli (web/mobil/yazılım teknolojileri vb.) araç, hizmet ve uygulamalar ile desteklenmesi sonucunda ortaya çıkan sanal platformlar olarak tanımlayabiliriz.

İçerdiği özellikler ve sunduğu hizmetler çerçevesinde sosyal medyayı oluşturan platformların sistematik olarak sınıflandırıldığı birçok çalışma (Mayfield, 2008:6; Weinberg, 2009:9; Mangold ve Faulds, 2009:358; Kaplan ve Haenlein, 2010:62; Khan, 2013:2) mevcuttur. Bunlar arasında kullanıcıların pratik biçimde profil oluşturarak birbirleriyle iletişime geçtiği ve arkadaşlıklar kurduğu, paylaşımda bulundukları, paylaşılan içeriklerle ilgili yorumda bulundukları ve birçok ilgi alanında sosyal toplulukların oluşturulmasına uygun ortamı sağlayan sosyal ağlar, tüm dünyada milyarlarca kullanıcıya sahip ve en çok ziyaret edilen web siteleri olarak dikkat çekmektedir.

Sosyal medyanın niçin kullanıldığına dair yapılan bir araştırmada ise, kullanım yüzdesine göre sırasıyla sosyal etkileşim, bilgi arama, zaman geçirme, eğlenme, rahatlama, fikir açıklama, iletişim aracı olarak kullanım, kullanımda kolaylık, bilgi paylaşımı, başkaları hakkında araştırma/bilgi toplama şeklinde on farklı neden ortaya konmuştur (Whiting ve Williams, 2013:362). Burada belirtilenlerle sınırlı kalmamak üzere sosyal medya uygulamalarının; politika ve siyaset, pazarlama ve ticaret, reklam, eğitim, insan kaynakları, halkla ilişkiler, iletişim/haberleşme ve habere ulaşma gibi daha birçok alanda geleneksel yöntemlere karşı yeni bir akımı ve anlayışı ortaya çıkardığı bilinmektedir.

Mobil cihazların yaygınlığı ile internete erişimde ve kullanımda sunduğu kolaylıkların yanı sıra, sosyal medya platformlarının tüm dünyada cazip bir iletişim ve etkileşim aracı haline gelmesinin önemli sebeplerinden bir tanesinin, uygulama sahibi şirketler tarafından genel olarak kullanıcılardan herhangi bir ücret talep edilmemesi olduğu düşünülmektedir. Ancak kullanıcılar tarafından herhangi bir ödeme yapılmasa da, sosyal medya şirketlerinin, sanal dünyada kullanıma sundukları uygulama ve platformlardan kazanç elde etmediklerini söylemek izahtan varestedir. Türkiye Cumhuriyeti Cumhurbaşkanlığı İletişim Başkanlığı Sosyal Medya Kullanım Kılavuzu'nda belirtildiği şekilde; somut olarak herhangi bir para ödenmemiş olsa da, sosyal medya üzerinden ücretsiz olarak sunulan hizmetler, kullanıcıların kendisini ürün haline getirmektedir. Dolayısıyla sosyal medya kullanıcıları, bu uygulamaları kullanarak kendi ihtiyaçlarını karşılamakla birlikte, aynı zamanda sosyal medya şirketleri için zaman ve mekândan bağımsız ve farkında olarak ya da olmayarak mesai harcayan bir çalışan haline dönüşmektedirler.

Kaplan ve Haenlein tarafından 2010 yılında ilgili yazında kabul görmüş sosyal medya tanımının yapıldığ 1 çalışmada (Kaplan ve Haenlein, 2010:67), Mobil Sosyal Medyanın bedelsiz olarak gelmediği, bu mecrada bir dünya dolusu arkadaşa sahip olunsa da kapı komşusunun bile adının bilinmediği bir topluluğun teşvik edildiği ifade edilerek avantajlarının yanı sıra sosyal medyanın getirdiği dezavantajlardan önemli bir tanesine dikkat çekilmiştir.

Herhangi bir sosyal medya platformuna kayıt esnasında sunulan bilgilerle birlikte, kullanıcilar tarafindan uygulamanın çalışması için erişim rızası verilen birtakım kişisel bilgiler (telefon rehberi, konum, cihaz bilgileri vb.) ya da uygulama üzerinden yapılan paylaşımlar ve üçüncü taraf sitelerine bağlantılar, sanal ortamda Büyük Verinin (Big Data) oluşturulmasına katkı sağlayan önemli faktörlerdendir. Belirtilen verilerin uzmanlar tarafindan analiz edilerek anlamlı hale getirilmesi ve kişiselleştirilmesi sonucunda, farkında olunmadan 
kullanıcıların yaşam tarzı, ilgi alanları, politik görüşleri vb. alanlara yönelik kişisel bilgileri elde edilmekte, bu bilgilerin reklam/tanıtım vb. amaçlarla üçüncü kişilere/firmalara iletilmesi de bundan yararlanmak isteyen herkese fayda sağlamaktadır. Örneğin, Google arama motorunda yapılan aramalardan elde edilen bilgilerin derlenmesi neticesinde, kullanıcılara herhangi bir markaya ya da kullanıcının ilgi alanına ve eğilimlerine yönelik YouTube ya da diğer sosyal medya uygulamalarından kişiselleştirilmiş reklam gönderilerek dikkatlerinin çekilmesi mümkün hale gelmektedir.

Dünya nüfusundaki artışa paralel olarak sosyal medya kullanımı da her geçen gün artmaktadır. Ocak 2021 verilerine göre, dünya nüfusunun \%53,6's1 (4.2 milyar), Türkiye nüfusunun ise \%70,8'i (60 milyon) aktif sosyal medya kullanıcısıdır ${ }^{1}$. Belirtilen istatistiklerdeki artma eğilimi devam ettiği müddetçe, mevcut sosyal medya uygulamalarına her geçen gün yenilerinin ilave edilmesinin kaçınılmaz olacağı ancak sağladığ sıra kişisel verilerin güvenliği, etik ve mahremiyet, trollük, sosyal mühendislik, siber zorbalık, nefret söylemi vb. birçok alandaki risklerin ve tartışmalı alanların da gündem yaratmaya devam edeceği düşünülmektedir.

İlk çıktıkları dönemde ifade özgürlüğünün sınırsızca kullanıldığı farklı bir mecra olarak hayatımıza giren sosyal medya, günümüzde ifade özgürlüğünün katı savunucuları da dâhil birçok ülke tarafından yasal düzenlemelerle kontrol edilmesi gereken bir alan olarak gelişimini sürdürmektedir. Sosyal medya şirketlerinin çoğunlukla ABD ya da kurulduğu ülkenin yasalarına tabi olması sebebiyle, bu şirketlerin ilgili ülkede yasal temsilci bulundurmamaları durumunda, bu alanda meydana gelebilecek hukuki süreçlerin takibi pek mümkün olmamakta, yargı makamlarınca vakalara ilişkin yapılan bilgi talepleri sosyal medya şirketlerince kabul görmemekte ya da süreç uzatılmaktadır.

Sosyal medyanın hayatımıza girdiği 2000'li yılların başından itibaren önemli bir sorun halini almış bu duruma çözüm olarak 5651 say1l "İnternet Ortamında Yapılan Yayınların Düzenlenmesi ve Bu Yayınlar Yoluyla Isslenen Suçlarla Mücadele Edilmesi Hakkında Kanuna" yakın dönemde değişiklikler yapılarak önemli bir adım atılmıştır. 04 Ocak 2021'de ise, dünya genelinde yaygın olarak kullanılan mobil/masaüstü sohbet ve anlık mesajlaşma uygulaması WhatsApp tarafından gizlilik sözleşmesinde değişiklik yapılarak uygulamanın kullanılabilmesi için yeni gizlilik sözleşmesi ve veri paylaşımı kurallarının kullanıcılar tarafından 08 Şubat 2021 tarihine kadar kabul edilmesi gerektiği aksi takdirde uygulamanın kullanılamayacağının bildirilmesi üzerine sosyal medya kaynaklı kişisel verilerin güvenliği konusu bir kez daha dünya ve Türkiye gündemine oturmuştur.

Açıklanan bilgiler çerçevesinde çalışmada; öncelikle sosyal medyaya ilişkin seçili ülkeler ve örgütler tarafindan yapılan/yapılmakta olan yasal düzenlemeler, müteakiben meselenin diğer tarafı olan sosyal medya şirketlerince oluşturulan Hizmet Sözleşmeleri ve Gizlilik Politikaları incelenmiş, son olarak gündemdeki yerli ve milli sosyal medya tartışmaları konusu irdelenerek birtakım önerilerde bulunulmuştur.

\section{SOSYAL MEDYAYA İLISSKKIN YASAL DÜZENLEMELER}

Günümüzde, sosyal ağ kullanıcıları, farkında olarak ya da olmayarak kişisel verilerini internet ortamına taşıma yarışına girmektedir. İnternetin yaygınlaşması ve sosyal medyanın dünyada ve Türkiye'de her geçen gün daha fazla insan tarafından kullanılır olmasıyla, bu mecrada kişisel verilerin nasıl korunduğu ve güvence altına alındığı konuları hem kullanıcılar hem de idareler tarafından daha da önemli ve sorgulanır hale gelmektedir. Ancak kişisel verilerin güvenliği ve gizliliği konusu sosyal medya ile başlayan yeni bir kavram olmayıp bu alandaki ilk düzenlemelerin çok daha önceki dönemlere kadar uzandığını belirtmek gerekir.

Sosyal medya, internet ve sanal mecrada üretilen veriyi ve bilgiyi artıran en temel kaynaklardan birisidir. Oluşturulan içeriklerin kontrolsüz bir şekilde büyümesiyle birlikte, bilgi kirliliğinin (disinformation), yanlış bilginin (misinformation) yanında doğrudan kişilik haklarıyla ilişkili ihlallerde de (manevi değerlerin ihlali, özel hayatın gizliliği ya da kişisel verilerin güvenliği ve korunmasındaki aksamalar ve ihlaller vb.) artış olması kaçınılmaz hale gelmiştir. Bu noktada, ülkeler tarafından vatandaşlarını özellikle sosyal medya kaynaklı risklerden korumak üzere bir takım yasal düzenlemelerin yapıldığı ve belirli mekanizmaların kurulması çerçevesinde önemli adımların atıldığı görülmektedir.

Sosyal medyaya ilişkin yasal düzenlemeler konusunda çalışma yapan tüm ülkelere ve örgütlere burada yer vermek mümkün olmadığından, aşağıda sosyal medya konusunda yasal düzenlemeleri ve çalışmaları bulunan farklı yönetim anlayışına sahip ülkeler ile Avrupa Birliği (AB) ve Birleşmiş Milletler (BM) uygulamaları incelenmiştir.

1 Detaylar için Bkz.: https://datareportal.com/reports/digital-2021-turkey (Erişim Tarihi: 17.02.2021). 


\subsection{Birleşik Krallık’ta Sosyal Medyaya İlişkin Yasal Düzenlemeler}

Birleşik Krallık’ta kişisel verilerin korunmasına yönelik temel yasal düzenlemelerin başında 2018 tarihli Data Koruma Yasası (Data Protection Act) gelmektedir. Yine 2018 y1lında "A $\breve{g}$ ve Bilgi Sistemleri Düzenlemeleri (The Network and Information Systems Regulations 2018)" adı altında başka bir yasal düzenleme de mevcuttur. Ancak her iki yasal düzenleme de, içerik itibarıyla sosyal medyadan kaynaklanan risklere karşı vatandaşları korumada yeterli güvenceyi vermemektedir. Bununla birlikte, yakın dönemde direkt olarak sosyal medya kaynaklı risklerle mücadele ve tedbirleri amaçlayan mevzuat çalışmalarında da önemli bir aşamaya gelindiği görülmektedir.

Birleşik Krallık’ta hükümetin, hassas bir kesim olarak gördüğ̈ çocukları odağına alan ayrıca tüm vatandaşlarını çevrimiçi mecralardaki bir takım zarar ve tehlikelerden (çocuk istismarı, siber zorbalık, terörizm, nefret söylemi vb.) koruyarak Birleşik Krallığ 1 sanal dünyada çok daha güvenli bir yer haline getirmek üzere 2019 y1lından itibaren başlattı̆̆ çalışmalar 2020 yılı sonlarında iyice hız kazanmış ve "Dijital, Kültür, Medya \& Spor Bakanlığı" ile "İçişleri Bakanlığı" tarafından ortak imzalı olarak hazırlanmış ve manifesto niteliği taşıyan teklifler (Online Harms White Paper: Full Government Response to the consultation) 15 Aralık 2020'de yasalaşması için Meclise gönderilmiştir (2021 yılı içerisinde yasalaşması öngörülmektedir). Aynı gün hükümetin resmi internet sitesinden yapılan basın duyurusunda ${ }^{2}$, Birleşik Krallığın sosyal medya için "hesap verilebilirliğin yeniçağında" öncülüğü elinde bulundurduğu ifade edilmiş ve bu alanda yapılacak düzenlemelerin herkes için daha güvenli ve müreffeh bir dijital geleceğin inşası için çok önemli bir adım olduğunun altı çizilmiştir.

Hükümetin uygulamaya koyduğu kuralların takip edilmesi ve gerektiğinde sosyal medya şirketlerine verilecek para cezası $^{3}$ ve diğer yaptırım işlemlerini yürütmek üzere bağımsız düzenleyici birim olarak İletişim Kurumunun (Office of Communications-Ofcom) yetkilendirildiği belirtilmiştir. Belirtilen yasa teklifinin en önemli özelliği, çocuklar başta olmak üzere diğer tüm vatandaşların açık bir şekilde sosyal medya kaynaklı risklere karşı korunmasının amaçlanması, kullanıcılarının dijital ortama olan güvenlerinin kazanılması ve sosyal medya şirketlerine de sorumluluklar getirilerek, gerektiğinde kendilerine yaptırım uygulanmasıdır.

\subsection{ABD'de Sosyal Medyaya İlişkin Yasal Düzenlemeler}

Sosyal medya uygulamalarının ilk ortaya çıtığı ülke olan ABD'de, 1975'te yürürlüğe giren Gizlilik Yasası (Privacy Act) dönemin koşulları içerisinde önemli bir gelişmedir. Bu yasada kişisel verilerin/kayıtların gizliliğinin korunması, açığa çıkarılma şartları belirtilmiş, aksi durumların vuku bulması durumundaki yaptırımlar hüküm altına alınmıştır. Sonraki yıllarda ise; kişileri çevrimiçi kaynaklı risklerden korumaya yönelik çıkarılmış yasalardan belli başlıları, 1996 tarihli İletişim Ahlakı Yasası (The Communications Decency ActCDA), 2000 tarihli Çocuklar İçin Çevrimiçi Gizliliğin Korunması Yasası (The Children's Online Privacy Protection Act-COPPA) olarak dikkat çekmektedir.

Yukarıdaki yasalara rağmen, ABD'de kullanıcılar tarafından yaratılan zararlı, riskli, uygunsuz ya da hukuk dışı içeriklerden dolayı sosyal medya şirketlerinin sorumlu tutulduğu herhangi bir düzenleme mevcut değildir. Bunun aksine İletişim Ahlakı Yasası'nın bir parçası olarak kabul edilen Bölüm 230'da (Section 230) "hiçbir etkileşimli bilgisayar servis sağlayıcısı ya da kullanıcısı, başka bir içerik sağlayıcı tarafindan sağlanan içeriğin yayıncısı olarak kabul edilemez" hükmü yer almaktadır. Bu hüküm sayesinde, ABD'de sanal mecrada yaratılan ve her türlü suç unsuru taşıyan ya da zararlı/uygunsuz içeriklere karşı sosyal medya şirketlerine yargı bağışıklığı sağlanmakta ve bu şirketler adeta yasal bir koruma şemsiyesi altına alınmaktadır.

Milyarlarca kullanıcıya sahip olan ve marka/bilinirlik ve kazanç açısından dünyada en ön sıralarda yer alan sosyal medya şirketleri, seçim dönemlerinde kendisinden yararlanan tarafa önemli katkılar sağlayan bir güce sahiptir. Örneğin, 2008 ABD seçimlerinde Obama tarafindan yürütülmüş sosyal medya kampanyalarının ve stratejilerinin ona seçimi kazandırmasında çok önemli rol oynadığına dair birçok araştırma ve inceleme mevcuttur (Aaker ve Chang, 2009:1; Borins, 2011:85; Genel, 2012:30). Ancak, 2020 y1lı ABD seçim

2 Basın duyurusu için Bkz.: https://www.gov.uk/government/news/uk-leads-the-way-in-a-new-age-of-accountability-forsocial-media (Erişim Tarihi: 31.01.2021).

3 Ceza miktarı, 18 milyon sterline kadar ya da şirketlerin küresel yıllık kazançlarının \%10'u ile mukayese edildiğinde büyük olan miktar kadar olabilmektedir. 
maratonunda sosyal medya, çok daha farklı bir özelliğiyle karşımıza çıkmıştır. Özellikle Twitter tarafından dönemin başkanı Trump'ın yaptığı birçok paylaşım politik açıdan hassas ya da sakıncalı bulunarak, yayımı durdurulmuş veya askıya alınmıştır. Bu durum, sosyal medya şirketlerinin seçim süreçlerine doğrudan bir müdahalesi ve siyasi olaylara/süreçlere karşı tarafsızlığının tartışılır hale gelmesine önemli bir örnek olarak değerlendirilmiştir. Bu sebeple, Trump döneminde Bölüm 230 ile sosyal medya şirketlerine verilmiş "sorumlu tutulmama" güvencesinin değiştirilmesine yönelik girişimlerde bulunulmasına rağmen, şu ana kadar herhangi bir sonuç alınmamıştır.

\subsection{Almanya'da Sosyal Medyaya İlişkin Yasal Düzenlemeler}

Almanya'da, internetteki nefret söylemi ve diğer yasa dışı sosyal medya paylaşımlarının ilgili sosyal medya şirketleri tarafından 24 saat içerisinde kaldırılmasını ve aksi takdirde para cezasını öngören ve kamuoyunda NetzDG olarak bilinen Ağ Yaptırım Yasası (Network Enforcement Act) 2018 yılında yürürlüğe girmiştir. Belirtilen yasadaki idari otorite olarak Adalet Federal Ofisi (Federal Office of Justice) tarafindan Facebook şirketine, 2019 yılında platformdaki yasa dışı içeriklerle ilgili gelen şikâyetleri raporlamaması üzerine 2 milyon avro üzerinde bir ceza takdir edilmiştir ${ }^{4}$. Alman A ̆ Yaptırım Yasası, aşağıda detayları açıklanan ve 31 Temmuz 2020’de yürürlüğe giren yasal düzenlemelerimize model teşkil etmesi açısından ayrıca önemlidir.

\subsection{Avustralya'da Sosyal Medyaya İlişkin Yasal Düzenlemeler}

Avustralya Hükümeti tarafından vatandaşlarını sosyal medya kaynaklı risklerden korumaya yönelik ilk kapsamlı düzenleme 2015 tarihli Çevrimiçi Güvenliğin Artırılması Yasasıdır (Enhancing Online Safety Act 2015). Bu yasa ile çocuklar başta olmak üzere vatandaşların siber zorbalığa karşı korunması ve çevrimiçi güvenliklerinin artırılması hedeflenmiştir. Belirtilen hedeflerin gerçekleştirilmesini sağlamak üzere ve çevrimiçi içeriklerin uygunluğunun takip ve kontrolü, şikâyetlerin değerlendirilmesi, raporlamaların yapılması, bu alandaki kılavuzların yayımlanması, nihayetinde Çevrimiçi Güvenliğin Artırılması Yasası'nın işletimini takip ve kontrol etmek üzere e-Güvenlik Komiserliği (eSafety Commissioner) teşkil edilmiştir.

5 Nisan 2019'da ise, Yeni Zelanda'da iki camiye gerçekleştirilen silahlı terör saldırılarının sosyal medya üzerinden canlı yayınlanması (Oymak, 2020:134) nedeniyle, kamuoyunda ortaya çıkan infialin de etkisiyle hükümet tarafından olaya hızla reaksiyon gösterilmiş ve 1995 tarihli Ceza Yasasına (Criminal Code Act 1995), Nefret Uyandırıcı Şiddet İçeren Materyalin Paylaşılması (Sharing of Abhorrent Violent Material) ismiyle önemli bir Kanun Değişikliği (Criminal Code Amendment Act 2019) yapılmıştır. Belirtilen değişiklik ile nefret uyandırıcı şiddet içeren (terör, adam öldürme, adam öldürmeye teşebbüs, işkence, cinsel saldırl, adam kaçırma eylemleri olarak belirtilmiştir) materyalin sanal mecrada yayınlanması ya da yapılan talebe istinaden içeriklerin kaldırılmaması halinde kişilere ya da sosyal medya şirketlerine önemli hapis ve para cezaları öngörülmüştür. Her iki yasal düzenlemenin de, Avustralya hükümeti tarafından doğrudan sosyal medya kaynaklı risklerin bertaraf edilmesi ve yeterli caydırıcılığı sağlamak üzere hazırlanmış önemli düzenlemeler olduğu düşünülmektedir.

\subsection{Fransa'da Sosyal Medyaya İlişkin Yasal Düzenlemeler}

2000 yılında Avrupa Birliği'nde iletişim/haberleşme alanında yapılan düzenlemelerin bir yansıması olarak Fransa'da, 2004 yılında Dijital Ekonomi Yasası yürürlüğe konmuştur. Bu yasa, her ne kadar direkt olarak sosyal medya platformları ve şirketlerine yönelik olmasa da, internet ve iletişim ortamındaki yasa dışı içeriklere yönelik kişilere ve servis sağlayıcılarına sorumluluklar yüklemektedir.

Müteakip süreçte ise, milletvekili Laetitia Avia öncülüğünde, Alman’ların NetzDG yasasına benzer ve çevrimiçi ortamda nefret söyleminin (hate speech) engellenmesine yönelik hazırlanan kanun teklifi (kamuoyunda "Avia Yasası" olarak bilinmektedir) 1 Temmuz 2020'de yürürlüğe girmek üzere 13 Mayıs 2020 tarihinde yasalaştırılmasına rağmen, muhalif milletvekillerden bir kısmı yasayı Fransız Anayasa Mahkemesine götürmüş ve Yüksek Mahkeme tarafından ifade özgürlüğüne aykırı olarak görülen ve yasanın ruhuna dair en önemli

4 Detaylar için Bkz.: https://www.dw.com/en/germany-fines-facebook-for-underreporting-hate-speech-complaints/a49447820 (Erişim Tarihi: 03.02.2021). 
maddeleri (nefret söylemine sahip içeriklerin fark edilmesi/şikâyetin üzerinden 24 saat içerisinde sosyal medya platformları tarafindan kaldırılması zorunluluğu gibi) iptal edilmiştir 5 .

Fransa Başkanı Macron tarafından 29 Ocak 2021 tarihinde uluslararası basına verilen demeçte ${ }^{6}$, 6 Ocak 2021 tarihinde yaşanan ABD Kongre Binası baskınına da atıfta bulunularak, sosyal medya platformlarının demokrasiye tehdit haline gelebileceği ve bu alanda düzenleme gerektiğinin altı çizilmiştir. Dolayısıyla Fransa'da Anayasa Mahkemesi başta olmak üzere bu alanda ifade özgürlüğünü savunan önemli bir kesim olsa da, sosyal medya şirketlerini kontrol altına almayı öngören yeni yasa tekliflerinin tekrar gündeme gelebileceği düşünülmektedir.

\subsection{Rusya Federasyonu (RF)'nda Sosyal Medyaya İlişkin Yasal Düzenlemeler}

Rusya Federasyonu'nda sosyal medya şirketlerini kontrol altına almayı ve Rus yasalarına göre yasa dışı olan içeriklerin bu şirketler tarafından kaldırılmasını öngören bir yasa (No: 530-FZ) Şubat 2021 başında yürürlüğe girmiştir ${ }^{7}$. Yasada, çevrimiçi yasa dışı içerikler; müstehcen çocuk görüntülerine, uyuşturucu kullanımına, intihara, reşit olmayanlar arasında paylaşılan tehlikeli aktivitelere ait bilgiler ile alkol ve kumara ilişkin reklamlar olarak sayılmıştır. Ayrıca insan itibarını ya da genel ahlakı bozucu, bununla birlikte toplumu, devleti, devletin sembollerini ya da kamu çalışanlarını itibarsızlaştırmaya yönelik tüm içeriklerin de yasaklandığ 1 belirtilmiştir. Önemli son kategori olarak da; kitlesel karışıklık, aşırılıkçılık, terörizm ya da izinsiz kitlesel gösterilere katılım çağrılarını kapsayan içerikler de yasak sayılmıştır.

Yasada, günlük ziyaretçi sayıları 500.000'i geçen sosyal medya şirketlerine belirtilen yasaklanmış içerikleri kaldırmadıkları takdirde 800.000 'den 4 milyon rubleye kadar (10.860'den 54310 dolara kadar), tekrarlanmas halinde ise şirketin yıllık gelirinin onda birine kadar para cezası verilmesi hükme bağlanmıştır. Uzmanlar tarafından, yeni yasanın yürürlüğe konmasının en muhtemel sebebinin, devlet tarafından ülkedeki artan memnuniyetsizlik ve protesto faaliyetlerini engellemeye yönelik bir hareket olduğu ifade edilmiştir.

\section{7. Çin'de Sosyal Medyaya İlişsin Yasal Düzenlemeler}

Diğer ülkelerle mukayese edildiğinde Çin, özellikle ABD menşeli sosyal medya platformlarına erişim engeli ile birlikte mevcut kullanılanlara da katı sansür ve gözetim uygulayan bir devlet konumundadır. Çinliler tarafından Altın Kalkan (Golden Shield) olarak adlandırılan bir sansür ve gözetim mekanizması ile Kominist Parti'ye muhalif olduğu değerlendirilen ve aralarında Facebook, YouTube, Twitter ve Instagram'ı da içeren onbinlerce web sitesine erişim engeli konmuştur ${ }^{8}$. Çin'de sadece sosyal medya içeriklerini monite eden ve denetleyen onbinlerce insan görev yapmaktadır. İnternetin merkezi olarak kontrol edilmesi (regulation) ve tüm sansür / gözetim uygulamalarının koordinesi Çin Siber Uzay İdaresi (Cyberspace Administration of China-CAC) tarafindan yürütülmektedir.

2010 yılında Çin Devlet Konseyi Bilgi Ofisi (SCIO) tarafından yayımlanan İnternet'in Çin'deki Durumu (The State of the Internet in China) isimli doküman, ülkede internet politikasını açıklayan en önemli resmi belgelerden biridir. $\mathrm{Bu}$ belgede, ülkede internetin gelişiminin desteklendiği belirtilmekte, başta internetin güvenli kullanımı dâhil olmak üzere internetin ülkede işletimine dair diğer kanun ve düzenlemelerden bahsedilmekte, en önemlisi belgenin tamamına yakınında internetin Çin Hükümeti tarafindan kanunlara uygun olarak yönetildiğinin ve ilgili düzenlemelerin yapıldığının altı çizilmektedir.

01 Haziran 2017'de yürürlüğe girmiş Siber Güvenlik Yasası da (Cybersecurity Law), internetin yürürlükteki kanunlara uygun olarak işletilmesi ve çevrimiçi mecradaki suçların engellenmesinde, ayrıca siber tehditlere karşı başta internet servis sağlayıcıları olmak üzere bu mecrayı kullanan herkese yükümlülüklerini ve aksi takdirde karşılaşacağı yaptırımları göstermesi bakımından önemli bir düzenlemedir.

5 Detaylar için Bkz.: https://www.lawfareblog.com/whats-going-frances-online-hate-speech-law (Erişim Tarihi: 03.02.2021).

6 Detaylar için Bkz.: https://www.wsj.com/articles/frances-macron-calls-for-regulation-of-social-media-to-stem-threat-todemocracy-11611955040 (Erişim tarihi: 04.02.2021).

7 Detaylar için Bkz.: https://globalvoices.org/2021/02/14/new-russian-law-demands-self-censorship-from-social-mediaplatforms/ (Erişim Tarihi: 17.02.2021).

8 Detalı bilgiler için Bkz.: https://www.washingtonpost.com/world/asia_pacific/chinas-scary-lesson-to-the-world-censoring-theinternet-works/2016/05/23/413afe78-fff3-11e5-8bb1-f124a43f84dc_story.html?utm_term=.a4d74a39f0a2; $\quad$ (Erişim Tarihi: 04.02.2021). 


\subsection{Hindistan'da Sosyal Medyaya İlişkin Yasal Düzenlemeler}

Hindistan'daki yasal düzenlemeler kapsamında, sosyal medyaya direkt olarak atıfta bulunmasa da, siber alanı düzenleyen ve bu mecradaki ihlallere karşılık gelen yaptırımları belirleyen en önemli gelişme Bilgi Teknolojileri Yasası (The Information Technology Act, 2000) olarak hayat bulmuştur. Bu yasanın sosyal medya şirketlerini yakından ilgilendiren en önemli özelliği, ABD örneğinde olduğu gibi, 2008 yılında yapılan mevzuat değişikliği ile sosyal medya şirketlerinin üçüncü taraflar tarafından yapılan paylaşımlardan dolayı sorumlu tutulmamalarıdır (Bilgi Teknolojileri Yasası Madde 79).

Belirtilen değişikliğin yürürlüğe girdiği tarihte şu anda milyarca kullanıcıya sahip olan sosyal medya platformlarından bazıları yoktu (Instagram, WhatsApp gibi) ya da mevcut kullanıcı sayılarına göre çok daha az kullanıcıya (Facebook'un 2008 yılında yaklaşık 100 milyon kullanıcı vardı) sahiptiler?. Bununla birlikte, sosyal medya platformları üzerinden nefret söyleminde bulunulması ya da işlenen suçlara bu platformların dâhil edilmesi de pek gündemde değildi.

2011 yılında Hindistan Hükümeti tarafindan sanal mecradaki aracı birimlerin (internet servis sağlayıcıları, arama motorları vb.) ve çevrimiçi içeriklerin düzenlenmesine yönelik detaylı usulleri içeren ve Bilgi Teknolojileri Yasası'nı destekler mahiyette Kuralların ${ }^{10}$ (IT - Intermediaries Guidelines Rules, 2011) yürürlüğe konduğu görülmektedir. Sosyal medya platformlarının tüm dünyada olduğu gibi, Hindistanda'da nefret söylemini iletmede ve şiddet içeren, konusu suç teşkil eden video/resim paylaşımlar için yaygın olarak kullanılması Hindistan Hükümeti'ni tekrar harekete geçirmiş ve 2018 yılında, 2011 yılında getirilen Kurallar'a değişiklik için çalışmalara (The Information Technology [Intermediaries Guidelines (Amendment) Rules, $2018^{11}$ ]) başlanmıştır. Belirtilen değişiklikler ile diğer ülke örneklerinde olduğu gibi Hindistan'da da sosyal medya platformları ve bunların sahibi şirketleri kontrol altına alarak belirli durumlarda onlara yasal sorumluluklar yüklemenin amaçlandığı anlaşılmaktadır. Sosyal medya şirketlerine Hindistan sınırları içerisinde temsilci bulundurma zorunluluğu da öngörülen söz konusu teklif henüz yürürlüğe girmiş değildir. Hindistan Üst Mahkemesinin de sürece dâhil olduğu dikkate alındığında, teklifin henüz yasalaşmamış olmasında, Fransa örneğine benzer şekilde, ifade özgürlüğünden kaynakların çekincelerin olduğu düşünülmektedir.

\subsection{Türkiye'de Sosyal Medyaya İlișkin Yasal Düzenlemeler}

Türkiye'de sosyal medyanın şu anki yoğunluğuyla hayatımıza girmesinden önce, internet ortamında işlenen suçlarla mücadelenin esaslarını oluşturan en önemli ve ilk yasal düzenleme 2007 yılında yürürlüğe giren 5651 sayılı Kanun'dur. Zaman içerisinde söz konusu Kanun'a çeşitli değişiklikler getirilmiş olsa da, direkt olarak sosyal medya platformlarını ve şirketlerini kapsayan en önemli değişiklikler, 31 Temmuz 2020 tarihinde Resmi Gazete'de yayımlanan 7253 sayılı Kanun ile yapılmıştır. Söz konusu değişikliklerin, yukarıda açıklanan Alman Ağ Yaptırım Yasası'nı (NetzDG) model alarak hazırlandığına ${ }^{12}$ (Akkurt, 2020:39) ve bu Yasa'dan ilham alındığına ${ }^{13}$ yönelik çeşitli görüşler bulunmaktadır.

7253 say1lı Kanun ile Türkiye'den günlük erişimi bir milyondan fazla olan sosyal medya şirketlerine Türkiye'de temsilci bulundurma zorunluluğu getirilmiştir. $\mathrm{Bu}$ şartı yerine getirmeyenlere ise kademeli olarak 10 milyon TL'den 30 milyon TL'ye kadar para cezası ile reklam yasağı ve internet band genişliğinin \%50'den \%90'a kadar yavaşlatılması yaptırımları öngörülmüştür. Ayrıca kişilik haklarının ihlal edilmesi ile ilgili durumlarda kendilerinden istenilen taleplere kırk sekiz saat içerisinde cevap verme yükümlülügü getirilmiştir. Bununla birlikte içeriğin çıkarılması talepleri ile erişimin engellenmesi konularında belirli aralıklarla rapor verme zorunluluğu öngörülmüsstür. Yine Türkiye'deki kullanıcıların verilerinin Türkiye'de depolanmasına yönelik tedbir alınması belirtilmiştiştir. Ayrıca, hukuka aykırılığı hâkim veya mahkeme kararı ile tespit edilen içeriklerin

9 Detaylar için Bkz.: https://www.barandbench.com/columns/regulating-content-in-the-age-of-social-media (Erişim Tarihi: 09.02.2021).

10 Detaylar için Bkz.: https://sflc.in/sites/default/files/wp-content/uploads/2014/07/Information-Technology- IntermediariesGuidelines-Rules-2011-An-Analysis.pdf (Erişim Tarihi: 09.02.2021).

11 Değişiklik çalışması metni için Bkz.: https://www.meity.gov.in/writereaddata/files/Draft_Intermediary_Amendment_24122018.pdf (Erişim Tarihi: 09.02.2021).

12 Konuyla ilgili bir haber için Bkz.: https://www.aksam.com.tr/guncel/almanya-modeli-ornek-alindi-sosyal-medyaduzenlemesinin-detaylari-belli-oldu/haber-1094824 (Erişim Tarihi: 11.02.2021).

13 TÜBIDER Bilişim Sektörü Derneği Sosyal Medya Raporu için Bkz.: https://tubider.org.tr/wpcontent/uploads/2020/08/Tubider-Sosyal-Medya-Yasasi-Raporu-24082020.pdf (Erişim Tarihi: 08.02.2021). 
yapılan bildirimle birlikte yirmi dört saat içerisinde kaldırılmaması durumunda, ilgili sosyal medya şirketlerine tazminat sorumluluğu yüklenmiştir.

Kanunun Genel Gerekçesi'nde ${ }^{14}$ iki temel hususun ön plana çıktı̆̆ı açıkça görülmektedir. Bunlardan ilki, internet kullanıcılarının kişisel başvurularında veya kamu kurumlarının bildirimlerinde yaşanan zorlukların aşılması için devletin sosyal ağ sağlayıcılarıyla muhataplık ilişkisi (temsilci atama zorunluluğu) kurmayı amaçlamasıdır. Diğeri ise, sosyal medya mecrasında öncelikle her türden nefret söyleminin ve suç oluşumunun önlenmesi, vatandaşların kişilik hakları ile özel hayatın gizliliğinin korunması amacıyla birtakım mekanizmalar kurulmasidır.

Twitter platformu tarafından yayımlanan ve ülkeler tarafından içeriklerin ya da hesapların kaldırılmasına yönelik talepleri ihtiva eden Ocak-Haziran 2020 dönemli şeffaflık raporunda ${ }^{15}$; tüm dünyadaki yasal taleplerin \%96'sının sadece 5 ülke (1. Japonya, 2. Rusya, 3. Güney Kore, 4. Türkiye, 5. Hindistan) tarafından yapıldığ 1 , ayrıca Türkiye'nin tarihsel olarak geçmiş raporlarda hep en üst sırada iken ilk kez son raporda 4'üncü sıraya gerilediği (tüm dünyada taleplerin \%10’u) belirtilmiştir. Twitter'ın kendisine iletilen içerik kaldırma ya da hesap kapatma taleplerine pek fazla olumlu yanıt vermediği de dikkate alındığında (en son raporda 42.220 talebin sadece \%31'ine içeriğin/hesabın kaldırılması yönünde işlem yapıldı̆̆ı belirtilmiştir), 7253 sayılı Kanun ile getirilen temsilci atama zorunluluğun yerinde bir karar olduğu değerlendirilmektedir.

Söz konusu Kanun yürürlüğe girdikten sonra Vkontakte, YouTube, TikTok, Dailymotion, LinkedIn, Facebook, Instagram ve son olarak 19 Mart 2021 tarihinde Twitter tarafından temsilci atama kararı alındığı duyurulmuştur. Mevcut yasanın gereği olarak, Nisan 2021'de temsilci atamayan platformların band genişliğinin öncelikle \%50 azaltılması, durumun devamı halinde ise Mayıs 2021'de band genişliğinin \%90 azaltılması öngörülmektedir ${ }^{16}$. Gelinen noktada, sosyal medya platformlarının Türkiye'de temsilci atamaya ilişkin reaksiyonları incelendiğinde, yürürlükteki sosyal medya yasasının bu konuda etkinlikle işletildiği ve amacına ulaştığı açıktır.

Kanun'un Ek Madde 4'ünün 5'inci fikrasını ayrıca değerlendirmek gerekli görülmüştür. Söz konusu fikrada, “Türkiye'den günlük erişimi bir milyondan fazla olan yurt içi veya yurt dışı kaynakl sosyal ă̆ sağlayıcl, Türkiye'deki kullanıclların verilerini Türkiye'de barındırma yönünde gerekli tedbirleri alır", hükmü yer almaktadır. Kanunda yer alan bu ifade, son yıllarda sosyal medyaya ilişkin devletin her kademesinde dile getirilen "Türkiye'nin Verisi Türkiye'de Kalmalı" söyleminin ilgili yasaya ithal edilmiş hali olması bakımından önemlidir. Ancak belirtmek gerekir ki, yasada bu hükmün gereğinin yapılmadığı durumlar için herhangi bir yaptırım öngörülmemiştir. Ayrıca, yabancı menşeli sosyal medya şirketlerinin Türkiye'deki kullanıcıların verilerini Türkiye'de depolaması işlemini nasıl gerçekleştireceğinin oldukça muğlâk bırakıldığı ve bu konudaki denetimin de pek mümkün görünmediği söylenebilir.

\subsection{Sosyal Medya İçeriklerine Karşı Uluslararası Örgütlerin Çalışmaları}

Ülkeler tarafindan sosyal medya kaynaklı risklerle mücadele için yukarıda belirtilen yasal düzenleme çalışmaları yapılırken, benzer çalışmaların küresel ölçekte bazı uluslararası örgütlerin de gündeminde olduğu tespit edilmiştir. Bu başlık altında Avrupa Birliği (AB) ve Birleşmiş Milletler (BM) tarafından yapılmakta olan çalışmalar incelenmiştir.

\subsubsection{Avrupa Birliği (AB)'nde Sosyal Medyaya İlişkin Yasal Düzenlemeler}

Kişisel verilerin korunması ile ilişkili olan ilk AB düzenlemeleri incelendiğinde; "95/46/EC Sayılı Verilerin Korunmasına İlişkin Direktif”, "2002/58/EC Sayıl Gizlilik ve Elektronik İletişime İlişkin Direktif (E-Gizlilik Direktifi)" ve "29. Madde Veri Koruma Grubunun Çevrimiçi Sosyal Ağlarla İlgili 5/2009 Sayıl Tavsiye Raporu" öne çıkmaktadır (Atasoy, 2016:279).

Sosyal medyanın tüm dünyada giderek yaygınlaşması ve özellikle kişisel verilerin korunması konusuna yaptığı etkiler de dikkate alındığında, yine AB tarafından 24 Mayıs 2016 tarihinde yürürlüğe konan ve 25 Mayıs

14 Kanun Gerekçesi’nin tam metni için Bkz.: https://www.tbmm.gov.tr/sirasayi/donem27/yil01/ss226.pdf (Erişim Tarihi: 11.02.2021).

15 Rapora ulaşmak için Bkz.: https://transparency.twitter.com/en/reports/removal-requests/2020-jan-jun.html (Erişim Tarihi: 14.02.2021).

16 Konuya ilişkin detaylar için Bkz:Sayan, 2021, https://twitter.com/ofatihsayan/status/1373017598972026885/photo/1 (Erişim Tarihi: 03.04.2021). 
2018'de uygulanmasına başlanan AB Genel Veri Koruma Tüzüğü (General Data Protection Regulation GDPR) önemli bir siyasal doküman olarak görülmektedir. Akıncı (2017:11) tarafından yapılan o dönemki adıyla Kalkınma Bakanlığı İktisadi Sektörler ve Koordinasyon Genel Müdürlüğü Çalışma Raporunda, belirtilen Tüzüğün ortaya çıkmasında en önemli etkenler olarak "Google-İspanya Kararı, İrlanda Dijital Haklar Kararı ve M.Schrems-Veri Koruma Komisyonu Kararı" gösterilmiştir ${ }^{17}$. Dolayısıyla GDPR'nin hazırlanma sebebinin doğrudan sosyal medya platformları kaynaklı riskler olduğunu söylemek yanlış olmayacaktır.

Yukarıdaki AB düzenlemelerinin devamı niteliğinde ve ülke uygulamalarında belirtildiği şekilde yine sosyal medya özelinde yasal düzenleme çalışmalarında hareketlilik yaşanmaktadır. Sanal mecradaki aracı servislerin (intermediary services) düzgün işleyişine katkı sunmak, tahmin edilebilir ve güvenilir bir çevrimiçi ortam sağlamak ile bu alandaki temel hakların korunmasını temin etmek üzere AB'nin "Dijital Çă̆ Stratejisinin" bir parçası olarak Avrupa Komisyonu tarafindan 15 Aralık 2020 tarihinde Avrupa Parlamentosu'na yeni bir "Dijital Servisler Yasası" ile birlikte 2000/31/EC Direktifi'nde değişiklik öngören bir Yasa Teklifi gönderilmiştir. Sonuç itibarıyla, son dönemde yaptı̆̆ mevzuat çalışmaları ile Avrupa Birliği de sosyal medya şirketlerini kontrol altına almayı amaçlayan bir tutum içerisindedir.

\subsubsection{Birleşmiş Milletler'de (BM) Sosyal Medyaya İlişkin Yasal Düzenlemeler}

BM tarafindan direkt olarak sosyal medyayı hedef alan düzenlemelerden önce, ifade özgürlügünü (freedom of expression) tanımlayan ve nefret söylemini yasaklayan en temel dokümanlardan biri kabul edilen ve 23 Mart 1976 'da yürürlüğe giren ${ }^{18}$ Medeni ve Siyasi Haklar Uluslararası Sözleşmesi'nin (International Covenant on Civil and Political Rights-ICCPR) ilgili maddelerine bakmak yerinde olacaktır.

Sözleşmenin 19'uncu maddesinde; herkesin, bir müdahale ile karşılaşmaksızın fikirlere sahip olma hakkı olduğu, bu hakkın ise başkalarının haklarına ve itibarına saygı ile ulusal güvenliği veya kamu düzenini veya sağlık ve ahlakı koruma maksatlarıyla sınırlandırılabileceği belirtilmiştir. 20'nci maddede ise, "Ayrımcılığa tahrik teşkil eden her türlü ulusal, ırksal veya dini nefreti savunmak, düşmanlık veya şiddet kanunla yasaklanacaktır", hükmü yer almaktadır.

BM bakış açısıyla, Medeni ve Siyasi Haklar Uluslararası Sözleşmesi'nde belirtilen ifade özgürlüğünün sınırlandırılmasının ancak belirli istisnalar halinde mümkün olabileceğinden hareketle, ifade özgürlüğü sınırlandırmaları için eşik/tolerans seviyesi yüksek tutulmuş (high treshold) ve konuya ilişkin farklı birçok şehirde (Cenevre, Viyana, Nairobi, Bankok, Santiago) yapılan çalışma toplantıları sonucunda Ekim 2012'de Rabat Eylem Planı (Rabat Plan of Action) benimsenmiştir.

Rabat Eylem Planı'nda özetle, bir ifadenin nefret suçuna teşvik (incitement to hatred) kapsamında suç olarak sayılabilmesi için "bağlam (context), konuşmacı/söylemi yapan kişi (speaker), kasıt (intent), içerik ve biçim (content and form), söylemin vardiğ boyut (extent of the speech act), yakılık dahil olmak üzere olabilirlik (likelihood, including imminence)" başlıkları olarak belirlenmiş altı kriter üzerinden teste tabi tutulması gerektiği ifade edilmiştir ${ }^{19}$.

Yakın dönemde, sosyal medya platformları kullanılarak çevrimiçi ortamda nefret söylemlerinin artmasıyla birlikte, BM tarafından sosyal medya platform ve şirketlerine karşı daha somut adımların atılmakta olduğu görülmektedir. Ağustos 2014-Temmuz 2020 döneminde görev yapmış BM Fikir ve İfade Özgürlüğü Özel Raportörü (David Kaye) tarafından iştirak edilen ve 1-2 Şubat 2019 tarihleri arasında Standford Üniversitesi'nde yapılan "Sosyal Medya Konseyleri: Konsepten Gerçekliğe" isimli konferans raporu ${ }^{20}$ incelendiğinde, insan hakları ve ifade özgürlüğünü temel alan ve yasa dışı ya da zararlı sosyal medya içeriklerine karşı mücadelede küresel ölçekte "Sosyal Medya Konseyi" adıyla çok paydaşlı (multi-stakeholder) bir yönetişim modeli teklif edilmiştir.

BM tarafından bu alanda atılmış bir diğer önemli adım Mayıs 2019'da onaylanan ve 18 Haziran 2019'da yürürlüğe giren "BM Nefret Söylemine Karşı Strateji ve Eylem Planı (United Nations Strategy and Plan of

17 Çalışma Raporuna ulaşmak için Bkz.: http://www.bilgitoplumu.gov.tr/wpcontent/uploads/2017/07/AB_Veri_Koruma_Tuzugu.pdf (Erişim Tarihi: 10.02.2021).

1816 Aralık 1966'da kabul edilmiş ve imzaya, onaya ve kabul edilmeye açılmıştır.

19 Detaylı açıklamalar için Bkz.: https://www.ohchr.org/Documents/Issues/Opinion/Articles1920/ThresholdTestTranslations/ Rabat_threshold_test.pdf (Erişim Tarihi: 28.02.2021).

20 Rapora ulaşmak için Bkz.: https://fsi-live.s3.us-west-1.amazonaws.com/s3fspublic/gdpiart_19_smc_conference_report_wip_2019-05-12_final_1.pdf(Erişim Tarihi: 01.03.2021). 
Action on Hate Speech)"dır. Strateji ve Eylem Planı'nda nefret söylemine karşı aşağıda belirtilen temel adımların atılması taahhüt edilmektedir;

- BM ilgili birimleri tarafindan nefret söyleminin izlenmesi ve analiz edilmesi,

- Nefret söyleminin temel sebeplerinin, itici güçlerinin ve aktörlerinin ortaya çıkarılması,

- Nefret söyleminin mağdurlarıyla iletişime geçilmesi ve desteklenmesi,

- İlgili aktörlerin bir araya getirilerek bağımsız arabulucu ve uzmanlık sisteminin tanıtılması,

- Yeni ve geleneksel medya ile ortaklıkların tesis edilmesi ve kuvvetlendirilmesi,

- Teknolojinin kullanılması, nefret söylemiyle mücadelede BM prensiplerinin ve eylemlerinin desteklenmesi için sosyal medya şirketleri ile irtibata geçilmesi,

- Eğitimin bir araç olarak kullanılması,

- Dijital dünyada insan haklarına saygı, ayrımcılık karşıtlığı, tolerans, diğer kültürler ve dinler ile cinsiyet eşitliği konularında farkındalığın artırılması,

- İletişim için rehberlerin geliştirilmesi,

- İlgili tüm aktörler (devlet, endüstri, sivil toplum vb.) arasında ortaklığın ve işbirliğinin teşvik edilmesi,

- BM çalışanlarının nefretle mücadele konusundaki ünsiyetlerinin geliştirilmesi,

- Üye devletlerin desteklenmesidir.

Kaye tarafından 9 Ekim 2019 tarihinde yayımlanan "Fikir ve Iffade Özgürlüğ̈̈ Hakkının Geliştirilmesi ve Korunmasl Raporu'nda ${ }^{21}$ (Promotion and Protection of the Right to Freedom of Opinion and Expression) ise, uluslararası insan hakları hukuku bağlamında, devletler ve sosyal medya şirketleri tarafindan çevrimiçi nefret söylemi ile mücadelede atılması gereken adımlara yönelik birtakım öneriler getirilmiştir.

BM Genel Sekreteri Antonio Guterres tarafindan 28 Ocak 2021 tarihinde yapılan açıklamada 22, "sosyal medya şirketlerinin elindeki gücün endişe verici olduğu ve düzenleyici mekanizmalar oluşturulması gerektiği" vurgulanmıştır. Yapılan açıklamanın, BM Nefret Söylemine Karşı Strateji ve Eylem Planı ile tamamen örtüştüğü ve gelinen noktada, ülke uygulamalarında olduğu gibi BM tarafından sosyal medya şirketlerinin mutlaka kontrol edilmesi gerektiği anlayışının benimsendiği görülmektedir.

\section{SOSYAL MEDYA HIZMET/GIZLILIKK SÖZLEŞMELERİ}

Sosyal medya kaynaklı risklerle mücadelede ilgili ülkeler ile $A B$ ve BM tarafından yukarıda açıklanmaya çalışılan yasal düzenleme örneklerinin yanı sıra, sosyal medya şirketleri de kendi düzenlemelerini yaparak ve gerektiğinde bu düzenlemeleri değiştirerek dönemin koşullarına kendilerini adapte etmektedirler. Belirtilen düzenlemeler "Sosyal Medya Hizmet ve Gizlilik Sözleşmeleri" olarak karşımıza çıkmaktadır. Aşağıda, dünya çapında ve Türkiye'deki belli başlı sosyal medya uygulamalarından Facebook, Twitter, YouTube, WhatsApp ve son olarak Türk kamuoyunda yerli ve milli sosyal medya platformu olarak ifade edilen BİP'e ait Hizmet ve Gizlilik Sözleşmeleri incelenmiştir.

\subsection{Facebook Gizlilik Sözleşmesi}

Hâlihazırda iki milyarı aşan kullanıcı sayısıyla sosyal medya platformları arasında en önde sayılan ${ }^{23}$ Facebook, 2004 yılında o dönem Harvard Üniversitesi öğrencisi olan Mark Zuckerberg tarafindan kurulmuş, yıllar içerisinde ciddi bir büyüme trendi içerisine girerek Instagram ve WhatsApp gibi diğer önemli sosyal medya şirketlerini de bünyesine katmıştır. Facebook Gizlilik İlkeleri, 11 Ocak 2021 tarihinde güncellenen en son sürüm üzerinden incelenmiştir.

21 Rapor metnine ulaşmak için Bkz.: https://www.undocs.org/A/74/486 (Erişim Tarihi: 28.02.2021).

22 Konuya ilişkin bir haber için Bkz.: https://www.reuters.com/article/us-un-guterres-socialmedia-idUSKBN29X2PU (Erişim Tarihi: 01.03.2021).

23 Ocak 2021 itibarıla, "facebook.com", "google.com” ve "youtube.com"dan sonra dünyada en çok ziyaret edilen 3. web sitesidir. Detaylar için Bkz.: https://wearesocial.com/digital-2021 (Erişim Tarihi: 17.02.2021). 
Facebook Gizlilik İlkelerinin bir alt başlığı olan Veri İlkesi'nde; kullanıcılardan ne tür bilgilerin toplandığı, bu bilgilerin nasıl kullanıldığı, bu bilgilerin nasıl paylaşıldığı, Facebook şirketlerinin nasıl birlikte çalıştığı, kullanıcılar tarafından bilgilerin nasıl yönetildiği veya silinebildiği, yasal taleplerin nasıl yerine getirildiği veya zararın nasıl önlendiği, dünya genelindeki hizmetler çerçevesinde verilerin nasıl kullanıldığı ve aktarıldığ 1 açıklanmaktadır.

Ne tür bilgilerin toplandığı ile ilgili olarak sözleşmede, hesap oluşturma, içerik ve mesajı ya da diğerleriyle kurulan iletişimi yaratma ya da paylaşma dâhil olmak üzere Facebook ürünleri kullanıldığında kullanıcılar tarafından sağlanmakta olan tüm içerik, iletişim ve diğer bilgilerin toplanmakta olduğu açık bir şekilde belirtilmektedir. Toplanan bilgiler ise, bir resmin çekildiği yer ya da bir dosyanın yaratıldığ 1 tarih gibi detaylı metadata (üst veri) bilgilerini içermektedir. Bunun da ötesinde, Facebook üzerinden bağlantı kurulan diğer insanlar, sayfalar, hashtag'ler ve gruplar hakkında ve nasıl etkileşim kurulduğuyla ilgili önemli bilgilerin toplanmakta olduğu görülmektedir.

İnsanların birbirini bulmasına katkı sağlamak üzere rıza gösterilmesi halinde herhangi bir cihazdaki adres defteri, arama ya da mesaj kayıtlarının da toplandığı belirtilmiştir. Bununla birlikte, insanların Facebook'u nasıl kullandıkları, ne tip içerikler görüntülediği ya da paylaştığı, uygulamayı hangi zaman dilimlerinde ve sıklıkta kullandığı, çevrimiçi işlemlerde kullandığı kredi/banka kartı, kimlik, fatura, teslimat adresi ve iletişim bilgileri ile bağlantı kurulan cihazlardan alınan bilgiler (cihazın işletim sistemi, donanım ve yazılım sürümleri, pil seviyesi, konum bilgileri, ăg ve şebeke bilgileri, IP adresleri, çerez bilgileri vb.) ve son olarak Facebook'la ortak çalışan diğer şirketlerden de önemli bir bilgi akışı (yapılan alışverişler, görülen reklamlar gibi) sağlanmaktadır.

Toplanan bilgilerin nasıl kullanıldığına ilişkin sözleşme incelendiğinde, ilk belirtilen husus toplanan bilgilerin kişiselleştirilmiş özellikler ve içerikler olarak (haber, reklam, pazarlama mesajları vb.) tekrar kullanıcılara iletilmesi ve elde edilen bilgilerin ışığında dâhil olunabilecek sosyal gruplar ya da faaliyetler hakkında kullanıcıya özel tercihler sunulması olarak dikkat çekmektedir. Facebook'un bu işlemi yaparken, kullanıcı bilgilerinin sadece Facebook platformu ile sınırlı kalmadığı, bu bilgilerin Instagram, WhatsApp, Messenger, Oculus gibi diğer grup şirketleri ile de karşılıklı olarak transfer edildiği unutulmamalıdır. Böylelikle kullanıcılara ait kişisel bilgilere sahip veri havuzunun iyice genişletildiğinin altını çizmek gerekir. Belki daha da önemlisi, yine sözleşmede, ziyaret edilen internet siteleri/reklamlar gibi Facebook ürünleri dışındaki kullanıcı hareketlerinin de Facebook şirketine, reklam verenlere ya da diğer ortaklarına aktarılmış olduğu belirtilmektedir.

Konum bilgisi toplanması kapsamında, cihaz konum bilgisinin kullanıcı iznine tabi olduğu belirtilse de, IP adresine ilişkin böyle bir kısıtlama olmadığından her halükarda Facebook tarafından kullanıcı konum bilgisine sahip olunmaktadır. Aynı zamanda, kullanıcının kendi iradesiyle kendisini belirli bir yerde ya da faaliyette etiketlemesiyle de (check-ins) konum bilgisi direkt olarak paylaşılmaktadır. Sözleşmede, toplanan verilerin ürünlerin geliştirilmesi ve test edilmesi amaciyla da kullanıldığı, aktif edildiği takdirde fotoğraf, video ve kamera içeren kullanımlarda yüz tanıma teknolojisine yer verildiği belirtilmiştir.

Bilgilerin nasıl paylaşıldığına yönelik sözleşmede, Facebook’ta paylaşılan bir içeriğin paylaşılan kişi ya da gruptakiler tarafindan Facebook ürünlerini ve hizmetlerini kullanan veya kullanmayan herkese kontrolsüz bir şekilde yayıldığı vurgulanarak kullanıcıların dikkati çekilmiştir. Yine sözleşmede; "Hiçbir bilginizi kimseye satmıyoruz ve asla satmayacağız” şeklinde bir slogana yer verilse de, reklamveren üçüncü taraflara kullanıcılara ait bilgilerin açık bir şekilde paylaşıldığı ve reklamveren şirketlerden de kazanç elde edildiği aşikârdır. Facebook, kendisini geçmiş yıllarda büyük çapta veri ihlallerinin yaşandığı olayların merkezinde bulmuştur ve bu sebeple Facebook için "Veri İlkeleri”" açısından sabıkalı bir şirket tabirini kullanmak yanlış olmayacaktır. Cambridge Üniversitesi'nde görevli bir profesör tarafından 87 milyon kullanıcıya ait Facebook kişisel bilgilerinin 2016 ABD Başkanlık seçimlerini Trump lehine etkilemek üzere Cambridge Analytica isimli şirkete satılması olarak özetlenebilecek veri ihlali olayının 2018 yılında ortaya çıkması sonucu yapılan soruşturma neticesinde, Facebook şirketine Federal Ticaret Komisyonu (FTC) tarafından 5 milyar dolar ceza kesilmiş ve şirketin CEO'su Mark Zuckerberg tarafından kamuoyundan özür dilenmiş ve alınacak tedbirler bildirilmiştir (İvren, 2019:143-145).

Yasal taleplerin nasıl yerine getirildiği konusunda sözleşmede; yasal taleplere (mahkeme kararları vb.) ilişkin (ABD dışındaki yargılamaların da dâhil olduğu belirtilmiştir) olarak düzenleyici kurumlar ve kolluk kuvvetlerine bilgi sağlanabileceği ancak bu bilginin verilebilmesi için, ilgili yasaların dikte ettiği paylaşım yapılması gerekliliğine yönelik şirket tarafindan da iyi niyet inancına (good faith belief) sahip olunması şart koşulmuştur. Benzer şekilde şirketin kendisini, kullanıcıları ya da diğerlerini korumak maksadıyla yasa dışı, zararlı ve şiddet içeren içeriklere karşı harekete geçme reaksiyonunun da yine iyi niyet inancına bağlı olduğu ifade edilmiştir. Kısaca, Facebook tarafindan mahkemeler başta olmak üzere, yapılan tüm yasal taleplere (ABD 
içi veya dışı) karşl1ık vermede, "iyi niyet inancı!” adı altında bir uygulamanın sözleşmeye dâhil edilmesiyle tamamen yoruma açık, tartışmalı ve muğlak bir alan yaratılmış olmaktadır.

\subsection{Twitter Hizmet Sözleşmesi ve Gizlilik Politikası}

2006 y1lında Jack Dorsey tarafından geliştirilen ve dünyadaki en güçlü çevrimiçi topluluklarından biri olarak kabul edilen Twitter'ın ${ }^{24}$ Hizmet Sözleşmesi ve Gizlilik Politikası 18 Haziran 2020 tarihli en son sürüm üzerinden incelenmiştir.

Hizmet Sözleşmesi'nde, Twitter'da paylaşılan içeriğin kullanıcı tarafından özel bir kısıtlama koyulmadıysa tamamen küresel ölçekte tüm kamuya açık olduğu ve yayılımı sağlamak üzere her türlü veri işlemesinin yapılacağı vurgulanmıştır. Paylaşılan içeriklere ilişkin, içeriği yaratanın direkt ve yegâne sorumlu olduğuna, şirket tarafından içeriklerin monite ve kontrol edilemeyebileceği ve içerikler için sorumluluğun alınamayacağı belirtilerek eğer içerik hassas bilgi taşıyorsa dikkatli olunması gerektiğine sözleşmede yer verilmiştir.

Telif ve marka hakkı ihlalleri, fikri mülkiyet haklarının suistimali, kimliği gizleme, yasa dışı davranış ya da taciz vb. sözleşmeye aykırı olan durumlarda içeriğin kaldırılma hakkının saklı tutulduğu belirtilmekle birlikte, buradakilerle sınırlı kalmamak üzere, genel olarak sözleşme kuralların ihlaline, şirkete risk ya da muhtemel hukuki sonuç doğurabilecek durumların olduğuna ve yasa dışı içeriklerden dolayı hesabın kaldırılmasına inanıldığında da, ilgili hesabın askıya alınabileceği ya da sonlandırılabileceği belirtilmektedir.

Gizlilik Politikasının önsözünde, kullanııların kendilerinden hangi verilerin toplandığını ve bunların nasıl kullanıldığını her zaman bilmeleri gerektiği, ayrıca bunların her ikisi üzerinde anlamlı bir kontrole sahip olmaları gerektiğine inanıldığı belirtilmiş ve şirketle paylaşılan bilgiler hakkında en iyi kararların verilmesi için kullanıcıların güçlendirildiği ifade edilmiş̧tir. Son olarak, bu hususların da Gizlilik Politikasının temel amacı olduğunun altı çizilmiştir.

Twitter Gizlilik Politikası'nda, Facebook sözleşmesinde olduğu gibi, hesabın yaratılmasından itibaren kullanıcıya ait bilgilerin (kullanıcı adl, şifre, e-posta, telefon numarası, konum, IP ve cihaz bilgileri, çerezler, gönderilen bağlantılar üzerinden erişsim sağlanan web siteleri $v b$.) toplandığ 1 ve bu bilgilerin diğer ortaklarla, şirketlerle ve reklamverenlerle paylaşıldı̆̆ 1 belirtilmektedir.

Kartopu etkisi benzetmesinde olduğu gibi, içeriğin katlanarak geniş kitlelere kısa sürede ulaşmasında en etkili sosyal medya platformlarından biri kabul edilen Twitter platformu, tüm dünyada siyasi kişilikler ve liderler tarafından da yaygın olarak kullanılmaktadır. Twitter, özellikle 2020 yılı ABD Başkanlık seçim yarışında ve 06 Ocak 2021'de eylemcilerin Kongre Binasını bastığı ABD tarihine geçen olaylar silsilesinde, dönemin ABD Başkanı Trump'un içeriklerine defalarca kısıtlama getirilmesi ve nihayetinde hesabının askıya alınması, benzer şekilde son dönemde Türkiye'den de bazı siyasilerin paylaştı̆̆ içeriklerin Twitter ilkelerine aykırı bulunarak engellenmesi gibi olaylarla gündemde yer tutmaya devam etmektedir.

\subsection{YouTube Hizmet Sözleșmesi ve Google Gizlilik Politikası}

2005 yılında kurulan ve 2006 yılında Google firması tarafından satın alınan video paylaşım uygulaması YouTube $^{25}$, dünyada en fazla ziyaret edilen sosyal medya uygulamasıdır. 10 Aralık 2019 tarihli Hizmet Sözleşmesinde; "Geçerli yasaların izin verdiği ölçüde, YouTube ve Satış Ortaklarının herhangi bir kullanıcı tarafindan gönderilen içerik veya herhangi bir kullanıcının iftira edici, rahatsı edici veya yasa dışı bir davranışından dolayı sorumlu olmayacăğ" belirtilmektedir.

YouTube'un Google tarafından satın alınmış bir uygulama olması sebebiyle, gizlilik politikası dokümanının, "Google Gizlilik Politikası" adıyla yürürlükte olduğu görülmüştür. Söz konusu doküman incelendiğinde; diğer sosyal medya platformlarının kullanıcılardan topladığı bilgilerin ve bunları kimlerle (reklamverenler, ortaklar vb.) ve nasıl paylaşıldığına dair uygulamaların YouTube için de geçerli olduğu tespit edilmiştir. Sözleşmede kullanıcılara ait bilgilerin, hizmetlerin sağlanması, sürdürülmesi ve geliştirilmesi, içerik ve reklamlar dâhil olmak üzere kişiselleştirilmiş hizmetlerin sağlanması, performans ölçümü, iletişim kurma, kullanıcıları ve

24 Ocak 2021 itibarıyla dünyada en çok ziyaret edilen dördüncü web sitesi konumundadır. Detaylar için Bkz.: https://www.similarweb.com/top-websites/ (Erişim Tarihi: 13.02.2021).

25 Google'ın ardından dünyasının en çok ziyaret edilen ikinci web sitesidir. Detaylar için Bkz.: https://www.similarweb.com/top-websites/ (Erişim Tarihi: 14.02.2021). 
kamuyu koruma maksatlarıyla toplandığı belirtilmiştir. Google bünyesinde faaliyet göstermesi sebebiyle, özellikle dünyanın en çok ziyaret edilen internet sitesi "Google.com" üzerinden yapılan aramalar da YouTube'a önemli derecede veri akışı sağlamaktadır.

Gizlilik Politikası'nda; yasal gerekçelerle bilgilerin Google dışında paylaşılması hususunda şirket tarafından Facebook'ta olduğu şekilde, vakaya ilişkin iyi niyet inancının gerekli olduğu belirtilmiştir. Veri aktarımı konusunda ise, dünyanın farklı yerinde veri merkezlerine ${ }^{26}$ sahip olunduğundan ve verilerin yaşanılan ülke dışındaki merkezlerde işleniyor olabileceğinden bahsedilmektedir. Dolayısıyla, 7253 sayılı Kanun ile getirilen değişiklikte yer alan "Türkiye'deki kullanıcıların verilerinin Türkiye'de depolanması"na yönelik maddeyle çelişkili bir durum söz konusudur.

\subsection{WhatsApp Hizmet Koşulları ve Gizlilik İlkeleri}

2014 yılında Facebook tarafından satın alınan WhatsApp, 2 milyardan fazla kullanıcısıyla dünyada en çok ziyaret edilen 14'üncü web sitesi ve en fazla kullanıcıya sahip 3'üncü sosyal medya platformudur ${ }^{27}$. WhatsApp Hizmet Koşulları ve Gizlilik İlkeleri 04 Ocak 2021 tarihinde güncellenen doküman üzerinden incelenmiştir. WhatsApp hizmet koşullarında; içerik ve verilerin dünyanın farklı noktalarındaki veri merkezlerine ve sistemlerine dağıtılarak buralarda depolandığı belirtilmektedir. Ancak web sitesi ve arama motorları üzerinden yapılan araştırmada, veri merkezlerinin nerelerde konuşlandırıldığı bilgisine ulaşılamamıştır. Facebook'a bağlı bir şirket olarak aynı veri merkezlerinin kullanılması ihtimal dâhilindedir.

WhatsApp Gizlilik İlkelerinde; mesaj içeriklerinin ve aramaların uçtan uca şifrelenme özelliği ile sadece iletişimi gerçekleştirilen taraflar arasında kaldığı, bu verilerin depolanmadığı, sadece teslim edilmeyen mesajların 30 gün süreyle muhafaza edildiği ifade edilmektedir. Ancak sosyal medya şirketlerinin sahip oldukları teknoloji, veri işleme yetenekleri ve belirli zaman aralıklarıyla karıştıkları veri ihlali olayları birlikte değerlendirildiğinde, WhatsApp'ın da mesaj içeriklerine ve yapılan görüşmelere isterse nüfuz edebildiği ve buradan elde ettikleri bilgileri anlamlı hale getirerek reklam vb. amaçlarla başka platformlar üzerinden tekrar kullanıcılara sundukları düşünülmektedir. Kaldı ki, hizmet sözleşmesinde kendi hizmetleriyle entegre çalıştığı belirtilen iCloud veya Google Drive gibi üçüncü taraf yedekleme sistemlerine veri transferi yapıldığında, bu bilgilerin tamamı (örneğin mesaj içerikleri) WhatsApp ile de paylaşılmış olunmaktadır.

WhatsApp, diğer sosyal medya şirketlerinde olduğu gibi kullanıcılara ait birçok bilgiyi (telefon numarasl, cihaz bilgisi, son görülme bilgisi, konum bilgisi, IP, internet servis sağlayıcı/operatör bilgileri, başka kullanıcıların sağladığ bilgiler $v b$.) otomatik olarak toplamakta ve işbirliği halinde olduğu firmalarla paylaşmaktadır. Bilgilerin toplanmasında ve işlenerek aktarılmasında; hizmetlerin yürütülmesi, sağlanması, iyileştirilmesi, özelleştirilmesi ve desteklenmesi temel gerekçeler olarak gösterilmektedir. 04 Ocak 2021 tarihinde yapılan son değişikliğin temelini, kişisel verilerin Facebook şirketlerine, diğer iş ortaklarına ya da üçüncü taraflara aktarılması oluşturmakta ve hâlihazırda reklam almayan WhatsApp'ın yeni sözleşme sonrası reklam almama politikasını değiştirip değiştirmeyeceği merak konusudur.

WhatsApp tarafından hizmet koşullarında yapılan değişikliğin onaylanması için kullanıcılara 08 Şubat 2021 tarihine kadar süre tanınmış ve yeni sözleşme onaylanmadığ taktide kullanıcıların WhatsApp hizmetlerinden yararlanamayacağı belirtilmiştir. Uygulamanın kullanılmaya devam edilebilmesi için yeni sözleşmenin onaylanmasının şart koşulması bir anda Türk kamuoyunda geniş yankı bulmuş ve WhatsApp'a karşı tepkiler oluşmaya başlamıştır. Kişisel Verileri Koruma Kurumu (KVKK) tarafindan, WhatsApp'ın getirdiği düzenlemelerin 6698 sayılı Kişisel Verilerin Korunması Kanununa ve bu Kanun'da yer alan "Açık Rıza" hükümlerine uyumluluğunun kontrolü maksadıyla WhatsApp hakkında 12 Ocak 2021 tarihinde res'en inceleme başlatılmasına karar verilmiştir ${ }^{28}$. Müteakiben KVKK tarafindan WhatsApp'a tebligatta bulunarak bilgi ve belge talebinde bulunulmuştur.

WhatsApp'a karşı ayrıca Rekabet Kurulu tarafindan 11 Ocak 2021 tarihinde, “Facebook'un Türkiye'de, WhatsApp kullanıcllarının verilerinin 08.02.2021 tarihinden itibaren başka hizmetler için kullanılmasina yönelik getirdiği koşullar ile ilgili olarak, 4054 sayılı Rekabetin Korunması Hakkında Kanun'un 9. maddesi

26 Kuzey Amerika'da 13, Güney Amerika'da 1, Avrupa'da 5 ve Asya'da 2 yerde olmak üzere toplam 21 veri merkezi bulunmaktadır.

27 Siralama "Similarweb" sitesine göredir. Detaylar için Bkz.: https://wearesocial.com/digital-2021 (Erişim Tarihi: 17.02.2021).

28 KVKK Kamu Duyurusu için bakınız: https://www.kvkk.gov.tr/Icerik/6856/WHATSAPP-UYGULAMASIHAKKINDA-KAMUOYU-DUYURUSU (Erişim Tarihi: 14.02.2021). 
çerçevesinde geçici tedbir kararı alınması gerektiği" dosya konusu ile yapılan inceleme ve değerlendirmeler neticesinde, yeni koşulları kabul eden veya bilgilendirmeyi alarak kabul etmeyen tüm kullanıcılara Facebook'un veri paylaşımını içeren yeni koşulları durdurduğunu anılan tarihe kadar bildirmesi şeklinde geçici tedbir alınmasına oybirliğiyle Karar (Karar Sayısı: 21-02/25-10) verilmiştir ${ }^{29}$. WhatsApp tarafindan, gerek KVKK gerekse Rekabet Kurulu kararlarından dolayı, belki de gelen tepkilerin etkisiyle, değişikliklerin daha iyi anlatılabilmesi için güncellemelerin kabul tarihinin 15 Mayıs 2021'e ertelendiği bildirilmiş ${ }^{30}$ olsa da, şu ana kadar şirket tarafından geri adım atmaya yönelik herhangi bir emare gösterilmemiştir.

\subsection{BİP Gizlilik Politikası}

Tamamen Türk mühendisler tarafindan geliştirildiği belirtilen bir "anlık mesajlaşma" ve "sesli ve görüntülü görüşme" uygulaması olan BİP, 20 Haziran 2016 tarihinden itibaren hizmet sunmaya başlamıştır ${ }^{31}$. BİP Gizlilik Politikası, 14 Ocak 2021 tarihli doküman üzerinden incelenmiştir. BïP Gizlilik Politikası'nın giriş kısmında, 6698 sayılı Kanun, verilerin serbest dolaşımına ilişkin AB Genel Veri Koruma Tüzüğü (GDPR) ve diğer ilgili mevzuata göre kişisel verileri korumaya ve güvenliğini sağlamaya kararlı olunduğu ifade edilmiştir. Söz konusu politika incelendiğinde, BİP tarafından da yukarıda belirtilen sosyal medya şirketlerince yapıldığ gibi benzer bilgilerin (kimlik ve iletişim bilgileri, kullanım bilgileri, kişiselleştirme bilgileri ve anketler, konum ve cihaz bilgileri, yedekleme bilgileri, adres defteri bilgileri) toplandığ 1 ve bu bilgilerin iş geliştirme, hizmet kalitesinin ölçümü ve iyileştirilmesi, tanıtım, pazarlama, reklam, profilleme gibi amaçlarla işlendiği belirtilmektedir.

BİP tarafından ayrıca, gerek kendisi gerekse üçüncü kişilerin haklarını, mülkiyetini veya güvenliğini korumak maksadıyla kişisel verilerin yasal yükümlülükler doğrultusunda adli makamlar, düzenleyici kurumlar ve diğer taraflar ile paylaşılabileceği belirtilmiştir. Politika dokümanında "paylaşabilir" ş̧eklinde bir ifade kullanımının BIP'e bazı durumlarda inisiyatif sağlayabileceği, "diğer taraflar" ifadesinden hangi birimin kast edildiğinin net olmadığı, sonuç olarak tartışmaya açık ve muğlak bir alanın yaratıldığı düşünülmektedir.

BİP'in sunduğu "otomatik çeviri" fonksiyonu ile mesajların Microsoft veya Google hizmet sağlayıcılarıyla paylaşılabildiği belirtilmektedir. Dolayısıyla "çeviri” özelliğini aktif kullanıma açan bir kullanıcının gönderdiği mesajların Microsoft ya da Google ve bunlarla bağlantılı şirketlere ait yurt dışındaki veri merkezlerine aktarım ihtimalinin yüksek olduğu değerlendirilmektedir.

Anlık mesajlaşma ve görüntülü görüşme uygulaması WhatsApp ile karşılaştırıldığında, kişisel bilgileri toplama ve bu bilgilerin işlenmesi ve paylaşılması konusunda her iki sosyal medya platformu arasında kayda değer bir fark tespit edilmemiştir. Önemli bir fark olarak BİP gizlilik politikasında, sunucuların Türkiye'de bulunduğuna ve kullanıma ilişkin tüm verilerin Türkiye'de depolandığına vurgu yapılmıştır. BİP kullanıcıları "keşfet" linki üzerinden birçok farklı kategoride (eğlence \& bilgi, iş \& yaşam, haber, spor, oyun, teknoloji, vb.) hizmet veren üçüncü taraf uygulamalarına yönelebilmekte, dolayısıyla kullanıcı rızasıyla da olsa, BİP üzerinden kullanıcı verileri buradaki firmalara (üçüncü taraflara) aktarılabilmektedir. Sonuç itibarıyla, belirli istisnalar (çeviri uygulamasının kullanıldığı durumlar gibi) haricinde kullanıcıya ait veriler Türkiye'deki veri merkezlerinde depolanmış olsa da, uygulamanın sunduğu "keşfet" özelliği ile kullanıcılar iletişim kurma ihtiyaçlarının dışında bilerek ya da bilmeyerek çok daha fazla kişisel bilgisini BİP dışındaki firmalarla paylaşma eğilimine girmekte ya da buna teşvik edilmektedirler.

\section{YERLİ VE MILLI SOSYAL MEDYA TARTIŞMALARI}

WhatsApp tarafindan yukarıda belirtilen sözleşme güncellemesi yapılması zorunluluğunun ortaya çıkması ile birlikte yerli ve milli sosyal medya uygulamalarının kullanılması yönünde bir gündem oluşmuştur. Ancak yerli ve milli uygulamaların kullanılması konusundaki çalışmaların çok daha önceden başlatıldığı görülmektedir. 6 Temmuz 2019 tarihinde yayımlanan, "Bilgi ve Iletişim Güvenliği Tedbirleri” konulu ve 2019/12 say1lı Cumhurbaşkanlığı Genelgesinin altıncı maddesinde; "sosyal medya ve haberleşme uygulamalarına ait yerli uygulamaların kullanımı tercih edilecektir", hükmü yer almaktadır. Aynı ifadeye, anlık mesajlaşma güvenliğinin sağlanması kapsamında, T. C. Cumhurbaşkanlığı Dijital Dönüşüm Ofisi tarafından yayımlanan

29 Detaylar için Bkz.: https://www.rekabet.gov.tr/Karar?kararId=e3bd6f42-4954-4177-b4ee-7783d47c4131 (Erişim Tarihi: 18.02.2021).

30 Konuya ilişkin WhatsApp açıklaması için Bkz.: https://blog.whatsapp.com/giving-more-time-for-our-recent-update (Erişim Tarihi: 15.02.2021).

31 BİP'e ilişkin detaylar için Bkz.: https://www.turkcell.com.tr/servisler/BiP (Erişim Tarihi: 14.02.2021). 
Bilgi ve İletişim Güvenliği Rehberi'nde de (Temmuz 2020) yer verilmiştir. Gülaslan (2018:191) tarafindan yapılan başka bir çalışmada;

“Türkiye'de kullanılan sosyal medya platformlarının önemli bir bölümünün yurt dışındaki firmalar tarafindan işletilmekte olduğu, uygulamalara iliş̧kin kullanım şartlarının yine bu firmalar tarafindan yayımlanmakta olduğu, yargı yoluna başvurulması ya da bu firmalardan bilgi talep edilmesi durumunda ilgili ülkelerin yasalarının ve şartlarının geçerli olduğu, bu durumun ise özellikle sosyal medya söz konusu olduğunda, hukuki çerçevede bazı kısitlamalara yol açabileceği, dolaylsiyla yabanci uygulamalarn kullanılmaya devam edilmesi ile birlikte, milli ve yerli sosyal medya platformlarının ortaya çıkarılabilmesi için yeterli teknoloji ve uzmanlığa sahip olunduğu ve bu alanda çalışmalara başlanabileceği",

ifade edilmiştir. "Yerli ve milli sayılabilmesi için sosyal medya platformu ve ilgili sistemler hangi özelliklere sahip olmalıdır?" sorusu, yerli ve milli sosyal medya tartışmasında cevaplanması gereken en temel sorudur. Bu çerçevede, birbiriyle direkt bağlantılı üç kriterden bahsetmek mümkündür. Bunlardan ilki ve en önemlisi, sosyal medya uygulaması üzerinden yaratılan, paylaşılan ve işlenen tüm verilerin depolandığı veri merkezlerinin, güvenliği sağlanmış biçimde ilgili ülkenin sınırları içerisinde ve kontrolünde olması gerektiğidir. Veri merkezlerindeki sunucuların ve burada kullanılan yazılımların yönetimi ve tam kontrolüne sahip olunması ikinci bir kriter olarak sayılabilir. Kullanılan yazılımların milli olarak geliştirilmesi arzu edilebilir olsa da yerli ve milliliği belirlemede bir kriter olmadığı düşünülmektedir. Tüm kullanım/lisans hakları alınmış ve üzerinde tam kontrol sahibi olunan yabancı menşeli bir yazılımı da kullanmak mümkündür. Üçüncü kriter ise, haberleşmeyi sağlayacak altyapının (internet altyapısı gibi) da ilgili ülkenin kontrolünde olması ve güvenli olarak işletilmesidir.

Dünya örneklerine bakıldığında, Ocak 2021 itibarıyla 300 milyon üzeri kullanıcıya sahip 17 sosyal medya uygulamasının 6 adedi (WeChat, Tiktok, QQ, Douyin, Sina Weibo, Kuaishou) Çin'de geliştirilmiştir ${ }^{32}$. Çin'in ABD menşeli sosyal medya platformlarına getirdiği sansür/yasaklamaların belirtilen sosyal medya uygulamalarının ortaya çıkma sürecini hızlandırdığını söylemek yanlış olmayacaktır. Çin, bu kapsamda kendi yerli ve milli sosyal medya markasını meydana getirdiği görünmektedir. Rusya'da da, ABD menşeli sosyal medya platformlarına erişim sağlanabilmekle birlikte kendi sosyal medya markalarını oluşturma kapsamında (VK ya da VKontakte örneğinde olduğu gibi) önemli adımlar atılmıştır.

“Türkiye'nin Verisi Türkiye'de Kalmalı” politikasını destekleyen yerli ve milli sosyal medya çalışmalarını, 5651 sayılı Kanun'a yapılan en son değişikliklerle birlikte analiz etmek gerekmektedir. Söz konusu Kanun'la yabancı menşeli sosyal medya platformlarına temsilci atama zorunluluğu getirilerek, yabancı sosyal medya şirketleri ile ilgili hukuki süreçlerde yaşanmakta olan mevcut sorunların asgariye indirilmesi ve muhataplığın tesis edilmesi amaçlanmıştır.

Yerli ve milli sosyal medya platformlarının Türk yargı sistemine ve ilgili tüm mevzuata tabi olması sebebiyle, idare ve ona bağlı birimler (kolluk kuvvetleri gibi) açısından her türden yasa dışı sosyal medya paylaşımları ve siber olaylarla daha etkin mücadele edilebilecek, ülke sınırları içerisinde bulunan veri merkezleri, sunucu/yazılımlar ve haberleşme altyapıları ile yabancı uygulamalara göre kişisel verilerin güvenliği artırılmış olacak ve daha güvenli bir sanal ortamın tesisine katkı sağlanmış olacaktır.

Sosyal medya kullanııları açısından değerlendirildiğinde ise; verilerinin ülke sınırları (Siber Vatan) içerisinde kalacağından hareketle, yerli ve milli sosyal medya uygulamalarını kullananlar tarafından kişisel verilerinin güvenliği ve nasıl işlenmekte olduğu konularına yönelik endişelerinde bir miktar azalma olacağı tahmin edilmektedir.

Kısıtlı sayıda üniversite öğrencisi (159 kişi) arasında yapılan bir araştırmada (Özdemir ve Nacar, 2020:65), öğrenciler tarafından yerli ve milli sosyal medya platformlarını tercih etme nedenleri olarak; "yerli ve milli olması, milli ekonomiye katkı sağlaması, kültürel olarak kendine yakın bulma ve tamamen Türkçe olması" gibi nedenler ifade edilmiştir.

479 internet kullanıcısı ile yapılan başka bir araştırmada (Aslanyürek, 2015:138) ise, ankete katılanların $\% 84$ 'ü, "internet ve sosyal paylaşım sitelerinde bireylerin mahremiyetlerinin hükümetler, pazarlama şirketleri ve bilgisayar korsanları tarafindan ihlal edildiğì" ifadesine katılmış ya da kararsız kalmıştır. 542 kişinin katıldığı ve sosyal ağ sitelerinin dezavantajlarının sıralandığı başka bir çalışmada da (Fuchs, 2009:89), devlet,

32 Detaylar için bakınız: https://wearesocial.com/digital-2021 (Erişim Tarihi: 17.02.2021). 
şirket ve kişilerin yaptığ 1 gözetimlere sebebiyet veren veri suistimali, veri paylaşımı ya da verilerin korunması eksiklikleri \%57 ile en önde gelen dezavantaj olarak çıkmıştır.

Belirtilen araştırmalara paralel olarak, teknolojik gelişmelerle birlikte sosyal medya mecraları, gözetimin en fazla yapıldığı (Kalaman, 2019:575) mecraların başında gelmektedir. Dolayısıyla, bir kesim kullanıcı tarafından yapmış olduğu yazışmaların, görüşmelerin ve paylaşımların yerli ve milli sistemler üzerinden daha kolay takip edilebileceği düşüncesiyle yerli/milli sosyal medya uygulamaları tercih edilmeyebilir.

WhatsApp'ın hizmet koşullarında yapmayı planladığı değişiklik üzerine, Türkiye'de WhatsApp kullanımını bırakarak, yerli ve yabancı farklı alternatif uygulamalara yönelimler olmuştur. Tablo-1'de görüleceği üzere, 3-13 Ocak 2021 verilerine göre, dünyada 2 milyarı aşkın WhatsApp kullanıcısının Türkiye'deki kullanıcı sayısında 2 milyonluk bir azalma olmakla birlikte, toplam kullanıcı sayısı 40.3 milyonda kalmıştır. Bu periyotta, Telegram ve BİP gibi diğer benzer işlevli platformlar da, mevcut kullanıcı sayılarını önemli miktarda artırmıştır.

Tablo 1. Anlık Mesajlaşma Uygulamaları 1-13 Ocak 2021 Türkiye Kullanıcı Sayıları ${ }^{33}$

\begin{tabular}{|c|c|c|c|c|c|}
\hline Uygulama & $\begin{array}{l}1 \text { Ocak } 2021 \\
\text { Kullanıcı Sayısı } \\
\text { (milyon) }\end{array}$ & $\begin{array}{l}3 \text { Ocak } 2021 \\
\text { Kullanıcı Sayısı } \\
\text { (milyon) }\end{array}$ & $\begin{array}{l}13 \text { Ocak } 2021 \\
\text { Kullanıcı Sayısı } \\
\text { (milyon) }\end{array}$ & $\begin{array}{l}10 \text { Günlük } \\
\text { Değişim } \\
\text { (milyon) }\end{array}$ & $\begin{array}{l}10 \text { Günlük } \\
\text { Değişim } \\
\text { (Yüzde) }\end{array}$ \\
\hline WhatsApp & 42.6 & 42.3 & 40.3 & -2 & $-5 \%$ \\
\hline Telegram & 4.4 & 4.7 & 14.1 & 9.4 & $200 \%$ \\
\hline BiP & 3.9 & 3.7 & 9.1 & 5.4 & $146 \%$ \\
\hline TOPLAM & 50.9 & 50.7 & 63.5 & 12.8 & $25 \%$ \\
\hline
\end{tabular}

Yerli ve milli sosyal medya tartışmalarını sadece WhatsApp'ın yeni hizmet sözleşmesi olayına indirgemek meseleyi sınırlamaktan öteye gitmeyecektir. Ocak 2021 verilerine göre, Türkiye'deki 16 ila 64 yaşları arasındaki aktif internet kullanıcılarının \%94,5'i YouTube, \%89,5'i Instagram, \%87,5'i WhatsApp, \%79'u Facebook ve \%72,5'i Twitter kullanıcısıdır ${ }^{34}$. Bu nedenle, yerli ve milli sosyal medya tartışmaları bir yana, Türkiye'den her gün sosyal medya kullanıcısı milyonlarca kişinin kişisel verisinin, yurt dışında konuşlu mevkisi bilinen ya da bilinmeyen yüzlerce veri merkezinde toplandığını, işlendiğini ve paylaşıldığını söylemek abartılı olmayacaktır.

\section{SONUÇ YERINE}

Hâlihazırda dünya nüfusunun yarısından fazlası aktif sosyal medya kullanıcısıdır ve bu istatistikler her geçen gün artma eğilimi göstermektedir. Sosyal medyanın genel olarak arkadaşlık kurma, sosyalleşme gibi amaçlarla günlük hayatımıza girdiği ilk andan itibaren, bu mecranın ifade özgürlüğünün sınırsız şekilde aktarıldığı bir alan olup olmadığ1, kişisel verilerin gizliliği ve nasıl korunacağı, etik ve mahremiyete dair hususlar birer sorunsal ve tartışmalı alan olarak kalmaya devam etmektedir. İnsanlar, birçok sebeple (para kazanma, vakit geçirme, eğlence, kendini kanıtlama, beğenilme arzusu vb.) günlük yaşantılarını sosyal medya ortamlarına aktarma ve teşhir etme yarışına girerken, bir taraftan kişisel verilerinin kontrolünü kaybetmekte ve gizlilik/güvenlik sorunlarının en temel kaynağı haline gelmekte, diğer taraftan farkında olarak ya da olmayarak sosyal medya platformlarına verdikleri kişisel verilerle sosyal medya şirketlerinin adeta bir elemanı/çalışanı haline dönüşmektedirler.

Sosyal medya platformları tarafından sunulan hizmetler ücretsiz gibi görünse de, kullanıcılar tarafindan sağlanan verilerin işlenerek anlamlı hale getirilmesi ve yeniden kullanılmasıyla (kişisel verilerin kişiselleştirilmiş reklam olarak kullanıcıya sunulması gibi) sosyal medya şirketleri bu süreçten önemli miktarda kazançlar elde ederek sürekli büyümektedirler. Sosyal medyanın kitleleri harekete geçirme potansiyeline yönelik Arap Baharı, ABD Başkanlık Seçimleri gibi örnekler göz önünde bulundurulduğunda, gelinen noktada bu platformlar onu kullanan kişilere, gruplara ya da kurumlara da fayda sağlamaktadır. Ancak, sosyal medyayı kapsayan yasal düzenlemelerdeki eksikliklerin de etkisiyle, bu alan bazı kesimler tarafından ifade özgürlüğünün sınırsızca kullanılabildiği, kontrolün olmadığı bir mecra olarak algılanmaktadır. Hatta bunun da ötesinde, sosyal

33 Kaynağa ulaşmak için Bkz.: https://www.haberturk.com/whatsapp-i-kac-kisi-sildi-kaci-bip-ve-telegram-a-gectihaberler-2939102-

teknoloji\#: :text=Ge\%C3\%A7en\%20pazar\%20g\%C3\%BCn\%C3\%BC\%20ile\%20birlikte,itibariyle\%2040.3\%20mily ona\%20ancak\%20geriledi. (Erişim Tarihi: 17.02.2021).

34 Detaylar için Bkz.: https://datareportal.com/reports/digital-2021-turkey (Erişim Tarihi: 17.02.2021). 
medyanın terör propagandası yapmak, siber zorbalık ve nefret söylemini yaymak da dâhil olmak üzere, her türden yasa dışı faaliyetin desteklenmesinde ve bir araç olarak kullanımında da artış gözlenmiştir. Bu nedenle, sosyal medya şirketlerini daha kontrol edilebilir ve hesap verebilir hale getirmeyi amaçlayan dünya çapında birçok yasal düzenlemenin yapıldığı/yapılmakta olduğu görülmektedir.

Sosyal medyaya ilişkin yasal düzenlemeler konusunda, Çin'de yapılan uygulamalar pek sürpriz değildir. Bu ülkede, ABD menşeli sosyal medya platformlarını kısıtlamak ve kontrol altına almak bir yana doğrudan yasaklama ve erişimine engel koyma yöntemi seçilmiş, bunun doğal bir sonucu olarak ise, Çin menşeli birçok sosyal medya platformu yaratılmış, bu uygulamalar ise sadece Çin'de değil küresel boyutta önemli kullanıcı sayılarına ulaşmıştır. Bununla birlikte, dünyada internete sansürün en üst seviyede uygulandığı Çin'de sosyal medya platformları yerli ve milli olsa bile, burada paylaşılan tüm içeriklerin kelime bazında tarandığı ve sansür uygulandığı bilinmektedir. Dolayısıyla, yerli ve milli uygulama kullananların sayısındaki artış ve bu uygulamaların yaygınlığıyla doğru orantılı olarak, ülkeler tarafından bu platformların kontrolü ve denetimi daha kolay hale gelebilmektedir.

Diğer ülke uygulamalarına yönelik en dikkat çekici husus ise; ifade özgürlüğünün, demokrasinin beşiği kabul edilen birçok ülkenin bile, özellikle siber zorbalık, nefret söylemi, terör, çocuk istismarı, kişisel hakların ve veri güvenliğinin ihlali başta olmak üzere sanal mecrada suç oluşturmaya yönelik potansiyeli bakımından sosyal medya platformlarını sanal mecrada zaman zaman potansiyel bir tehdit olarak görmeleri ve kontrol etme çabalarıdır. Bu kapsamda; Türkiye'de Siber Vatan'ın güvenliğini sağlamak üzere, 5651 sayılı Kanun'a getirilen nihai değişiklikler, sosyal medya şirketleri ile direkt muhataplık tesis eden ve onlara ciddi sorumluluklar yükleyen önemli düzenlemeler içermektedir.

Sosyal medya kaynaklı riskler ve çevrimiçi nefret söylemiyle mücadelede, ülkeler tarafindan yapılan yasal düzenlemeler benzerlik gösterse de, bu konuda tam bir standardın yakalanması kolay değildir. Ancak, çok paydaşl1 yönetişim modeli olarak belirtilen "Sosyal Medya Konseyi" ile BM Nefret Söylemine Karşı Strateji ve Eylem Planı'nda yer alan bağımsız arabulucu ve uzmanlık sisteminin benzerlik taşıdığı, dolayısıyla çevrimiçi ortamda nefret söylemiyle mücadele kapsamında yapılan ulusal düzenlemelerin yakın gelecekte uluslararası ortama doğru evrilebileceği ve BM nezdinde uluslar üstü mekanizmaların kurulmasının muhtemel olduğu, bu sayede küresel ölçekte standartların oluşturulabileceği düşünülmektedir.

Ülkeler ya da $\mathrm{AB}$ ve $\mathrm{BM}$ gibi devletler üstü örgütler tarafından sosyal medyaya ilişkin düzenlemeler yapıllırken, diğer taraftan sosyal medya şirketleri de kendi hizmet sözleşmelerini ve gizlilik politikalarını güncellemektedirler. Ancak kullanıcılar, sosyal medya platformlarını kullanabilmeleri için kayıt olma sürecinin son aşamasında ortaya çıkan ve uzun metinlerden oluşan, tamamı okunsa dahi anlaşılması zor hizmet sözleşmelerini çoğu kez okumadan onaylamak zorunda kalmaktadırlar. Hizmet sözleşmelerinde ve gizlilik politikalarında geçen muğlâk ifadeler ise, vuku bulan olayların ya da sosyal medya işletimine dair uygulamaların sosyal medya şirketleri tarafından keyfi yorumlanmasına sebebiyet vermekte ve netice olarak kullanıcıların aleyhine durumlar ortaya çıkabilmektedir.

İster siyasi, ister medyatik/sanatçı, isterse sıradan bir vatandaş olsun, milyonlarca takipçiye (follower) sahip bir Twitter kullanıcısının paylaştı̆̆ 1 bir içeriğe politik hassasiyet, ilkelere aykırılık vb. nedenlerle kısıtlama koyulması ya da hesabın askıya alınması durumlarının toplum nezdinde büyük bir etki oluşturduğuna, zaman zaman infiale bile neden olabildiğine şahit olunmaktadır. Eğer bu engellemeler seçim dönemlerinde gerçekleşirse, kısıtlamaya uğrayan tarafın aleyhine bir seçim sonucun ortaya çıkması bile mümkündür.

Twitter açısından konu en basit şekliyle hizmet sözleşmesinin ihlali şeklinde açıklanabilir ancak içeriklerin kısıtlanması ya da hesapların askıya alınması kararları, Twitter'ı zaman zaman yetkisi olmadığı halde sözde "Kamu Otoritesi” haline dönüştürme riski taşımaktadır. Twitter'ın bu konudaki sözleşme maddelerinin oldukça subjektif ifadeler içermesinden dolayı, bir taraftan politik hassasiyet gerekçesiyle içeriklere kısıtlama getirilirken ve hesaplar askıya alınırken ya da sonlandırılırken, diğer taraftan siber zorbalık yapan, nefret söyleminde bulunan ya da terör örgütlerini destekleyen/propagandasını yapan hesaplar (ifade özgürlüğü gerekçesiyle!) açık kalmaya devam etmektedir. Bu nedenle, Twitter'ın özellikle siyasi içerikler kapsamında tarafsızlığını koruduğunu söylemek mümkün görünmemektedir.

Belirtilen durumun sebeplerinden birisinin de, başlangıçta iletişim kurma ve sosyalleşme amaçlarıyla kurulmuş olan ancak zaman içerisinde milyarlarca dolarlık ciroya sahip hale gelen sosyal medya şirketlerinin gelinen noktada sahip olduğu gücünü ve gelirini daha da genişletme çabasından olabileceği değerlendirilmektedir. Hatta ülkelerin kamu politikası oluşturma ve karar alma süreçlerinde önemli bir unsur olan vatandaşların davranışlarını etkileyerek ve algılarını ölçmeye çalışarak zımmen de olsa yine kendilerine kazanç sağlamayı amaçladıkları düşünülmektedir. 
Herhangi bir sosyal medya şirketinin kullanıcılardan topladığı verileri, kendi ortakları ya da üçüncü taraflarla paylaşmasının kontrol ve fark edilmesinin zorluğundan hareketle, diğer sosyal medya şirketleri tarafından yapıldığı gibi WhatsApp tarafindan da yeni sözleşme öncesi dönemde toplanan kişiler bilgilerin Facebook gibi ortaklar, reklamverenler ve işbirliğinde bulunan üçüncü taraflarla zaten paylaşllıyor olabilme ihtimalini de göz önünde bulundurmak gerekmektedir. Bu nedenle, geçmişte veri ihlallerinin ortaya çıkmasıyla büyük miktarda para cezasına hükmedilen ve dünya çapında itibar kaybı yaşayan Facebook'a bağlı bir şirket olan WhatsApp tarafından, getirilmek istenen yeni sözleşme ile mevcut uygulamaların hukuki altyapısının sağlamlaştırılmaya çalışıldığı ve Facebook ile paylaşılan bilgiler üzerinden yakın gelecekte kullanıcılara reklam sunma uygulamasına başlanabilme ihtimali bulunmaktadır.

İster yerli ve milli, ister yabancı menşeli olsun, sosyal medya kullanan bir bireyin bilerek ya da bilmeyerek birçok önemli kişisel verisini bu platformlarla ve/veya bu platformlar üzerinden hizmet/gizlilik sözleşmelerinde belirtilen üçüncü taraflarla paylaştığı bilinen bir gerçektir. Sosyal medya kullanıcısı tarafından paylaşılan bilgiler (ya da sosyal medya platformlarınca otomatik olarak toplanan veriler), yurt içi ya da yurt dışındaki veri merkezlerine aktarıldığından, belirli istisnalar hariç her iki durumda da kişinin bu veriler üzerindeki kontrolü ortadan kalkmış olmaktadır. Bu nedenle, veri güvenliği açısından yerli ve milli uygulamalar ile yabancı menşeli uygulamalar arasında anlamlı bir fark görmeyen kullanıcılar, yabancı uygulamaların küresel boyuttaki bilinirliği ve popülerliğinin de etkisiyle bu platformları kullanmaya devam edecektir.

Yerli ve milli sosyal medya platformlarının kullanılması ve bu yönde adımlar atılması Türkiye'de resmi bir devlet politikası haline gelmiştir. ABD menşeli platformlarla birlikte, başarılı olmuş Çin ve Rus örneklerinin de yerli ve milli sosyal medya uygulamalarını ülke çapında yaygınlaştırmak için model olarak kullanılması ve bu alanda kamu, özel sektör ve kullanıcı olarak vatandaşların da sürece dahil edildiği eylem planlarının hayata geçirilmesi ihtiyacı bulunmaktadır. Dolayısıyla yerli ve milli sosyal medya çalışmalarında "Türkiye nin Verisi Türkiye'de Kalmalı" ilkesini gerçekleştirmek üzere üretilmiş/üretilecek yerli ve milli sosyal medya uygulamalarının öncelikle kullanıcı ihtiyaçlarını gözetmesi ve ülkemizin markasını yaratacak nitelikte olması önemlidir.

Tüm dünyada sosyal medyaya ilişkin getirilen yasal düzenlemeler, neyin kabul edilebilir neyin kabul edilemez sosyal medya içeriği olduğunun belirlenmesine katkı sağlasa da, yine de sosyal medya içerikleri üzerinden yapılan eleştirinin sınırının nerede bittiğini, suç unsurunun nerede başladığını kestirmek pek kolay değildir. Özellikle politik mecra söz konusu olduğunda, hangi içeriğin toplumda hassasiyet yaratacağı tamamen göreceli bir kavramdır ve hangi politik görüşe sahip olunduğuna bağlı olarak farklı yorumlar yapılabilir. Bu sebeple, gerek sosyal medya şirketleri gerekse Kamu Otoriteleri tarafından yasal düzenlemelere ya da mahkeme kararlarına göre konusu suç teşkil etmediği müddetçe, sosyal medya içeriklerine kısıtlama getirilmemesi gerektiği düşünülmektedir.

\section{KAYNAKÇA}

AAKER, Jennifer ve CHANG, Victoria (2009), "Obama and the Power of Social Media and Technology", Standford Graduate School of Business, Case: M-321 (E-Article), ss.1-40, https://www.gsb.stanford.edu/gsb-box/route-download/352051 (Erişim Tarihi: 03.02.2021).

AKINCI, Ayşe Nur (2017), Avrupa Birliği Genel Veri Koruma Tüzüğü’nün Getirdiği Yenilikler ve Türk Hukuku Bakımından Değerlendirilmesi Çalışma Raporu-6, Kalkınma Bakanlığı İktisadi Sektörler ve Koordinasyon Genel Müdürlüğü Yayını, Ankara.

AKKURT, Sinan Sami (2020), “7253 Sayıl Yeni Sosyal Medya Yasasının Getirdikleri”, Selçuk Hukuk Kongresi 2020 Özel Hukuk Tebliğleri Tam Metin Kitabı, Nobel Akademik Yayınc1lı,, Ankara, ss.3952.

ASLANYÜREK, Malik (2015), "İnternet Güvenliği ve Çevrimiçi Gizlilik Alanlarında Yaşanan Sorunlar: Internet ve Sosyal Medya Kullanıcılarını Internet Güvenliği ve Çevrimiçi Gizlilik ile İlgili Kanaatleri ve Farkındalıkları Üzerine Bir Araştırma", Yüksek Lisans Tezi, Gazi Üniversitesi Sosyal Bilimler Enstitüsü, Ankara.

ATASOY, Kemal (2016), "Kişilik Hakkı Kapsamında Sosyal Medyada Kişisel Verilerin Korunması ve Veri Sahibinin Rızası", Marmara Üniversitesi Hukuk Fakültesi Hukuk Araştırmaları Dergisi, S.22(3), ss.269-301. 
BORINS, Sanford (2011), “Online Adaydan Online Başkana”, Seçim Kampanyalarında Geleneksel Medya, İnternet ve Sosyal Medyanın Kullanımı (Ed. Yusuf Devran, Çev. Nazlı Çetin Turan), Başlık Yayın Grubu Yayını, İstanbul, ss.85-93.

BOYD, Danah (2008), “American Teen Sociality in Networked Publics”, Doktora Tezi, Berkeley Üniversitesi, Kaliforniya (USA).

ERTAŞ, Handan (2015), “Kamu Yönetiminde Sosyal Medyanın Kullanımı”, Kamu Yönetiminde Sosyal Medya, Kuramdan Uygulamaya (Ed. Handan Ertaş), Palet Yayınları, Konya, ss.15-42.

FUCHS, Christian (2009), Social Networking Sites and the Surveillance Society: A Critical Case Study of the Usage of Studivz, Facebook, and Myspace by Students in Salzburg in the Context of Electronic Surveillance, ICT\&S Center Research Report, University of Salzburg, Vienna (Austria), https://citeseerx.ist.psu.edu/viewdoc/download?doi=10.1.1.168.4621\&rep=rep1\&type=pdf $\quad$ (Erişim Tarihi: 03.02.2021).

GENEL, Mehmet Gökhan (2012), "Siyasal İletişim Kampanyalarında Sosyal Medyanın Kullanımı (12 Haziran 2011 Seçimleri "Twitter" Örneği)", The Turkish Online Journal of Design, Art and Communication - TOJDAC October 2012, S.2(4), ss.23-31, http://www.tojdac.org/tojdac/VOLUME2ISSUE4_files/tojdac_v02i405.pdf (Erişim Tarihi: 03.02.2021).

GÜLASLAN, Taylan (2018), Kamu Yönetiminde Sosyal Medya Kullanımı ve Yönetimi, Nobel Bilimsel Eserler Yayını, Ankara.

IVREN, Burçin (2019), "Sosyal Medyada Gözetim: Facebook Veri Politikasına Yönelik Kullanıcıların Gizlilik Endişeleri ve Gözetim Farkındalı̆̆ Üzerine Bir Araştırma”, Yüksek Lisans Tezi, Ege Üniversitesi Sosyal Bilimler Enstitüsü, İzmir.

KALAMAN, Sefer (2019), "Yeni Medya ve Dijital Gözetim: Türkiye’deki Sosyal Medya Kullanıcıları Üzerine Bir Araştırma”, Celal Bayar Üniversitesi Yönetim ve Ekonomi Dergisi, S.26(2), ss.575-594.

KAPLAN, Andreas Marcus ve HAENLEIN, Michael (2010), "Users of the World, Unite! The Challenges and Opportunities of Social Media”, Business Horizons, S.53(1), ss.59-68.

KHAN, Gohar Feroz (2013), "The Government 2.0 Utilization Model and Implementation Scenarios", Information $\quad$ Development, $\quad$ S.31(2), ss.1-15, https://citeseerx.ist.psu.edu/viewdoc/download?doi=10.1.1.959.4849\&rep=rep1\&type=pdf $\quad$ (Erişim Tarihi: 03.02.2021).

MANGOLD, W. Glynn ve FAULDS, David J. (2009), "Social Media: The New Hybrid Element of the Promotion Mix”, Business Horizons, S.52, ss.357-365.

MAYFIELD, Antony (2008), What is Social Media?, iCrossing Publisher (E-Book), New York (USA), https://www.icrossing.com/uk/sites/default/files_uk/insight_pdf_files/What\%20is\%20Social\%20Media_i Crossing_ebook.pdf (Erişim Tarihi: 03.02.2021).

ONAT, Ferah (2010), “Bir Halkla Illişkiler Uygulama Alanı Olarak Sosyal Medya Kullanımı: Sivil Toplum Örgütleri Üzerine Bir İnceleme", Gazi Üniversitesi İletişim Fakültesi İletişim Kuram ve Araştırma Dergisi, S.31, ss.103-122.

OYMAK, Hasan (2020), "7253 Sayıl "Internet Ortamında Yapılan Yayınların Düzenlenmesi ve Bu Yayınlar Yoluyla İşlenen Suçlarla Mücadele Edilmesi Hakkında Kanunda Değişiklik Yapılmasına Dair Kanun'un Getirdikleri”, Ankara Hacıbayram Veli Üniversitesi İletişim Fakültesi Yeni Medya Dergisi, S.9, ss.129-141.

ÖZDEMİR, Kadir ve NACAR, Ramazan (2020), "Yerli ve Milli Sosyal Medyayı Tercih Etme Nedenleri", Süleyman Demirel Üniversitesi Sosyal Bilimler Enstitüsü Dergisi, S.38, ss.42-69.

SAFKO, Lon (2012), The Social Media Bible: Tactics, Tools and Strategies for Business Success, John Wiley and Sons Publisher, New Jersey (USA), Third Ed.

SAYAN, Ömer Fatih (2021), "Kişisel Tweet", Twitter Sosyal Medya Sayfası, https://twitter.com/ofatihsayan/status/1373017598972026885/photo/1 (Erişim Tarihi: 03.04.2021). 
SCOTT, Peter R. ve JACKA, J. Mike (2013), Sosyal Medya Kurumsal Yönetim ve Risk Rehberi (Çev. Tuğrul Bozbey), Türkiye İç Denetim Enstitüsü Yayını, İstanbul.

T. C. CUMHURBAŞKANLIĞI (2020), Bilgi ve İletişim Güvenliği Rehberi, Cumhurbaşkanlığı Dijital Dönüşüm Ofisi Yayını, Ankara, https://cbddo.gov.tr/SharedFolderServer/Genel/File/bg_rehber.pdf (Erişim Tarihi: 15.02.2021).

T. C. CUMHURBAŞKANLIĞI (2020), Sosyal Medya Kullanım Kılavuzu, Cumhurbaşkanlığı İletişim Başkanlığı Yayını, Ankara, https://www.iletisim.gov.tr/uploads/docs/SosyalMedyaKullanimKilavuzu.pdf (Erişim Tarihi: 27.01.2021).

TAŞCI, Ersin (2010), "Sosyal Medya Araçlarının Yerel Yönetimlere Etkisi ve Katkısı: Belediye 2.0”, Türkiye Bilişim Derneği Bilişim Dergisi, S.38(126), ss.23-26.

WEINBERG, Tamar (2009), The New Community Rules: Marketing On the Social Web, O'Reilly Media Inc., Kaliforniya (USA).

WHITING, Anita ve WILliAMS, David Lindsey (2013), “Why People Use Social Media: A Uses and Gratifications Approach”, Qualitative Market Research: An International Journal, S.16(4), ss.362369.

4054 sayılı Rekabetin Korunması Hakkında Kanun (13.12.1994 tarih ve 22140 sayılı Resmi Gazete).

5651 sayılı İnternet Ortamında Yapılan Yayınların Düzenlenmesi ve Bu Yayınlar Yoluyla İşlenen Suçlarla Mücadele Edilmesi Hakkında Kanun (23.05.2007 tarih ve 26530 sayılı Resmi Gazete).

6698 sayılı Kişisel Verilerin Korunması Kanunu (07.04.2016 tarih ve 29677 sayılı Resmi Gazete).

7253 sayılı İnternet Ortamında Yapılan Yayınların Düzenlenmesi ve Bu Yayınlar Yoluyla İşlenen Suçlarla Mücadele Edilmesi Hakkında Kanunda Değişiklik Yapılmasına Dair Kanun (31.07.2020 tarih ve 31202 sayılı Resmi Gazete).

2019/12 sayılı Cumhurbaşkanlığı Genelgesi (06.07.2019 tarih ve 30823 sayı1ı Resmi Gazete).

AB Dijital Servisler Yasası ile Birlikte 2000/31/EC Direktifi'nde Değişiklik Öngören Yasa Teklifi, https://eur-lex.europa.eu/legal-content/EN/TXT/PDF/?uri=CELEX:52020PC0825\&from=en (Erişim Tarihi: 09.02.2021).

AB Genel Veri Koruma Tüzüğü, https://eur-lex.europa.eu/legal-content/EN/TXT/PDF/?uri=CELEX: 32016R0679 (Erişim Tarihi: 10.09.2021).

AB 2000/31/EC Direktifi, https://eur-lex.europa.eu/legalcontent/EN/TXT/PDF/?uri=CELEX:32000L0031\&from=EN (Erişim Tarihi: 10.09.2021).

ABD Çocuklar İçin Çevrimiçi Gizliliğin Korunması Yasası, https://www.govinfo.gov/content/pkg/PLAW105publ277/pdf/PLAW-105publ277.pdf (Erişim Tarihi: 02.02.2021).

ABD Gizlilik Yasası, https://www.law.cornell.edu/uscode/text/5/552a (Erişim Tarihi: 01.02.2021).

ABD İletişim Ahlakı Yasası, https://www.law.cornell.edu/uscode/text/47/230 (Erişim Tarihi: 01.02.2021).

Alman A $\breve{g}$ Yaptırım Yasası, https://www.bmjv.de/SharedDocs/Gesetzgebungsverfahren/Dokumente/NetzDG_ engl.pdf?_blob=publication File \&v=2 (Erişim Tarihi: 03.02.2021).

Avustralya Çevrimiçi Güvenliğin Artırılması Yasası, https://www.legislation.gov.au/Details/C2017C00187 (Erişim Tarihi: 03.02.2021).

Avustralya Nefret Uyandırıcı Şiddet İçeren Materyalin Paylaşııması İsimli Kanun Değişikliği, https://www.legislation.gov.au/Details/C2019A00038 (Erişim Tarihi: 03.02.2021).

BİP Gizlilik Politikası, https://bip.com/tr/gizlilik-politikasi/\#BiPGIZLILIKPOLITIKASI (Erişim Tarihi: 12.02.2021). 
Birleşik Krallık Ăg ve Bilgi Sistemleri Düzenlemeleri, https://www.legislation.gov.uk/uksi/2018/506/made (Erişim Tarihi: 03.02.2021).

Birleşik Krallık Data Koruma Yasası, https://www.legislation.gov.uk/ukpga/2018/12/contents/enacted (Erişim Tarihi: 03.02.2021).

BM Nefret Söylemine Karşı Strateji ve Eylem Planı, https://www.un.org/en/genocideprevention/ documents/ advising-and-mobilizing/Action_plan_on_hate_speech_EN.pdf (Erişim Tarihi: 27.02.2021).

Çin Siber Güvenlik Yasası, https://www.newamerica.org/cybersecurity-initiative/digichina/blog/translationcybersecurity-law-peoples-republic-china/ (Erişim Tarihi: 04.03.2013).

Facebook Gizlilik İlkeleri, https://tr-tr.facebook.com/legal/terms (Erişim Tarihi: 12.02.2021).

Fransa Dijital Ekonomi Yasası, https://www.legifrance.gouv.fr/loda/id/LEGITEXT000005789847/ (Erişim Tarihi: 04.02.2021).

Google Gizlilik Politikası, https://policies.google.com/privacy?hl=tr (Erişim Tarihi: 14.02.2021).

Hindistan Bilgi Teknolojileri Yasası, https://www.indiacode.nic.in/bitstream/123456789/1999/3/A200021.pdf (Erişim Tarihi: 05.02.2021).

İnternet'in Çin'deki Durumu (The State of the Internet in China) İsimli Doküman, http://www.gov.cn/zhengce/2010-06/08/content_2615774.htm (Erişim Tarihi: 04.02.2021).

Medeni ve Siyasi Haklar Uluslararası Sözleşmesi (International Covenant on Civil and Political Rights), https://www.ohchr.org/documents/professionalinterest/ccpr.pdf (Erişim Tarihi: 28.02.2021).

Rabat Eylem Planı (Rabat Plan of Action), https://www.ohchr.org/Documents/Issues/Opinion/SeminarRabat/ Rabat_draft_outcome.pdf (Erişim Tarihi: 28.02.2021)

Twitter Hizmet Sözleşmesi ve Gizlilik Politikası, https://cdn.cms-twdigitalassets.com/content/dam/legaltwitter/site-assets/tos-oct-14th-2020/Twitter_User_Agreement_EN.pdf (Erişim Tarihi: 12.02.2021).

UK Online Harms White Paper: Full Government Response to the Consultation, https://assets.publishing.service.gov.uk/government/uploads/system/uploads/attachment_data/file/944310 /Online_Harms_White_Paper_Full_Government_Response_to_the_consultation_CP_354_CCS001_CS1 220695430-001_V2.pdf (Erişim Tarihi: 03.02.2021).

WhatsApp Hizmet Koşulları ve Gizlilik İlkeleri, https://www.whatsapp.com/legal/updates/terms-ofservice/?lang=tr (Erişim Tarihi: 12.02.2021).

YouTube Hizmet Sözleşmesi, https://www.youtube.com/t/terms (Erişim Tarihi: 14.02.2021). 